\title{
POHŘBÍVÁNÍ VE VRCHOLNÉM STŘEDOVĚKU A V NOVOVĚKU NA CHRUDIMSKU, PARDUBICKU A KOLÍNSKU
}

\author{
JAN FROLÍK
}

\begin{abstract}
Abstrakt: Od roku 2001 byly provedeny záchranné archeologické výzkumy u 23 středověkých a novověkých kostelu a dalši dva mimo tyto pohřebni areály. Na tomto základě jsou popsány pohřebni zvyklosti (úprava hrobové jámy, výskyt rakvi a hrobek, uloženi zemřelého, označeni hrobu), poznatky o rozděleni hřbitovni plochy (části s prevažujicími dětskými hroby, vymezení hřbitova) a způsoby zacházení s kostmi ze staršich hrobů. Připomenuta je náročnost provádèní podobných výzkumů a požadavky na terénni dokumentaci.
\end{abstract}

Klíčová slova: hřbitov - vrcholný středověk - raný novověk-pohřební ritus - etážové pohřbívání.

\section{Burials in the High Middle Ages and the Modern Age in the Chrudim, Pardubice and Kolín Regions}

Abstract: Rescue archaeological research has been conducted in the grounds of 23 medieval and modernage churches, as well as outside these sites, since 2001. Funeral rites (preparation of the pit, the occurrence of coffins and tombs, the interment of the deceased and the marking of graves), information about the division of the graveyard area (sections with children's graves, layout) and approaches to the bones from earlier graves are described on the basis of this research. The article also comments on the demanding nature of this kind of research and lists requirements connected with site documentation.

Key words: graveyard - high Middle Ages - early modern age - funeral rite - multilevel burials.

\section{1 Úvod}

Pohřbívání bylo a je významnou částí lidského života. Nejinak tomu bylo i ve vrcholném středověku a raném novověku. V této dlouhé periodě se běžné pohřební aktivity odehrávaly především na hřbitovech situovaných u kostelů, at' již farních nebo hřbitovních. Přibližně od roku 2001 je zejména na Chrudimsku a v přilehlé části Pardubicka prováděn systematicky pojatý záchranný archeologický výzkum související s opravami kostelů. Obvykle se jedná o aktivity, které mají vyřešit problematický statický stav jednotlivých staveb nebo se vypořádat s nadměrnou vlhkostí neblaze působící na stav stavby a její interiér.

Hlavním záměrem tohoto systematického sledování bylo určit počátky jednotlivých staveb $\mathrm{s}$ důrazem na př́ímou či nepřímou identifikaci těch, které mají své kořeny již v románském období. Kostelů, u nichž můžeme identifikovat románskou stavební část, je na Chrudimsku dochováno jen velmi málo (Merhautová 1971) a tato skutečnost neodpovídá zjištěním o intenzitě zdejšího středohradištního a především mladohradištního osídlení (Frolík-Sigl 1995). Vodítkem pro výběr staveb je seznam farností nově zřizovaného litomyšlského biskupství, zachycený v listinách z let 1349 až 1351 (Rojek 1871-1873), nebo starší archeologické nálezy (např. hroby se záušnicemi v blízkosti kostela) indikující přítomnost starší stavby. Předpokládané románské stáŕí se u některých staveb potvrdilo, at' přímo (např. nálezem zdiva - Přelouč) nebo nepřímo (porušení starších hrobů stojící stavbou [Jezbořice - Frolík-Mácalová-Stránská 2016], hroby s nálezy datovatelnými do mladohradištního období [Běstvina, Hrochův Týnec - Frolík 2006a; 2007]). Velkou část nálezů však tvořily vrcholně středověké nebo novověké pohřby (eventuálně i jiné situace). Jejich celkové množství (několik set hrobů) již umožňuje učinit některá obecnější pozorování a závěry.

Určité srovnání dovolují také výsledky dalších podobných výzkumů provedených autorem u skupiny kostelů na Kolínsku, prŕpadně na Kutnohorsku. Archeologická aktivita byla obvykle podnícena podobnými příčinami (statické zajištění, odvodnění či odvlhčení základů). Při těchto archeologických výzkumech byly získány nejen poznatky o počátcích jednotlivých církevních staveb, ale také (a někde jenom) o pohřbívání během vrcholného středověku až novověku. Převážná část výzkumů se odehrává na hřbitovech užívaných dodnes, je proto možné konfrontovat 
získané poznatky se současnými zvyklostmi. Předběžné shrnutí získaných poznatků a upozornění na otevřené problémy či otázky přináší tento text.

\section{Charakteristika problému, $\mathrm{k}$ metodice provádění výzkumů}

Počet záchranných archeologických výzkumů u církevních staveb, převážně kostelů, v posledních letech narůstá. Je to spojeno se zvýšeným počtem oprav a úprav, které jsou vyvolány obvykle dlouhodobě zanedbanou údržbou těchto objektů. Nejčastějším druhem stavebního zásahu je odvlhčení základů nebo jejich zpevnění. Obvykle je prováděno po vnějším obvodu kostela. V poslední době však narůstá počet stavebních úprav, při nichž je obdobné odvlhčení provedeno také podél vnitřních stěn. Pro archeologii má tato stavební aktivita zásadní význam, protože jsou při něm archeologické terény a situace odděleny od zdiva (základů) kostela. Zaniká tím základní stratigrafický vztah, bez něhož není možné archeologické nálezy správně interpretovat a někdy také datovat. Setkáváme se bohužel také s takovými př́ípady, že archeologové jsou pozváni k již vykopané rýze, eventuálně na vlastní výzkum terénů rezignují, obvykle s předpokladem, že postižena je pouze „nezajímavá“ hřbitovní vrstva s vícenásobně přemístěnými lidskými kostmi. Zájem se následně soustředí pouze na základová zdiva kostela.

Odhalovaná terénní situace, která je obvykle velmi složitá, klade značné nároky na terénní dokumentaci. Převažujícím nálezem jsou samozřejmě hroby, přičemž jenom jejich malá část je dochována v úplnosti (obvykle ty chronologicky nejmladší). Pečlivě dokumentovány proto musí být všechny skupiny kostí, u nichž se často až dodatečně dá určit, zda jsou torzem hrobu, nebo byly druhotně přemístěny. Nezbytné je pořizování dostatečného množství řezů odhalovanými situacemi, protože některé terénní detaily jsou rozeznatelné v ploše a jiné zase na řezu. Při provádění výzkumů se osvědčila fotogrammetrie, ale zároveň i pořizování obvyklé kresebné dokumentace. Na ní je možné zachytit detaily (především vzájemné vztahy jednotlivých skupin kostí), které jsou důležité pro stanovení následnosti jednotlivých pohřbů nebo pro stanovení správné příslušnosti kostí ke konkrétnímu hrobu, jež nemusí být na fotogrammetrickém záběru dostatečně zřetelné nebo jednoznačné. Samozřejmostí je fotografická dokumentace širších vztahů dotčené části terénní situace a podrobný slovní popis. Náročnost terénní situace (velký objem detailní preparace) i terénní dokumentace znamenají, že výzkum vrcholně středověkého či raně novověkého hřbitova patří k časově i finančně velmi náročným počinům.

\section{Chrudimsko a Pardubicko}

Výše bylo vzpomenuto, že hlavním kritériem pro výběr lokality k výzkumu je na základě starších nálezů nebo písemných zpráv předpokládaná existence románského kostela (obr. 1). Jejich maximální možný počet vychází z také již uvedeného seznamu farností litomyšlského biskupství (Rojek 1871-1873). Ostatních staveb se archeologické výzkumy dotkly jenom okrajově (Chrast, okr. Chrudim, kostel Nejsvětější Trojice, který byl postaven až v 17. století [ne zcela spolehlivá zmínka datuje postavení k r. 1618 - Frolík 2015a, s. 25], a nikdy se kolem něj nepohřbívalo). V některých př́padech archeologický výzkum neodhalil hrobové nálezy (Mikulovice, okr. Pardubice, kostel sv. Václava) nebo měly práce jinou povahu (Pařížov, okr. Chrudim, kostel sv. Máří Magdaleny, fotogrammetrická dokumentace zdiv románské stavební fáze stavby, dočasně zbavené omítky). Doloženy jsou i př́ípady, kdy byly odhaleny hroby raně středověké, a mladší nikoliv (Kostelec u Heřmanova Městce, okr. Chrudim, kostel sv. Petra a Pavla, jeden raně středověký hrob - Frolík 2012; Frolík-Stránská-Švédová v tisku; Podlažice, okr. Chrudim, kostel sv. Markéty, 75 hrobů s datováním před rok 1421 - Frolík 2004; 2005). Za určitý kontrolní vzorek můžeme považovat církevní stavby, u nichž je z písemných zpráv doloženo, že jsou mladší než vznik litomyšlského biskupství (Kočí, okr. Chrudim, kostel sv. Bartoloměje, 28 hrobů, kostel založen v roce 1397 - Frolík 2014a; 2015; 2015b; 2016), nebo se nacházejí v oblasti, která nebyla podle dosavadních hypotéz až do 13. století osídlena (Raná, okr. Chrudim, kostel sv. Jakuba). Zkoumané lokality zahrnují prostředí městské (Chrudim, kostel N. P. Marie - Frolík 


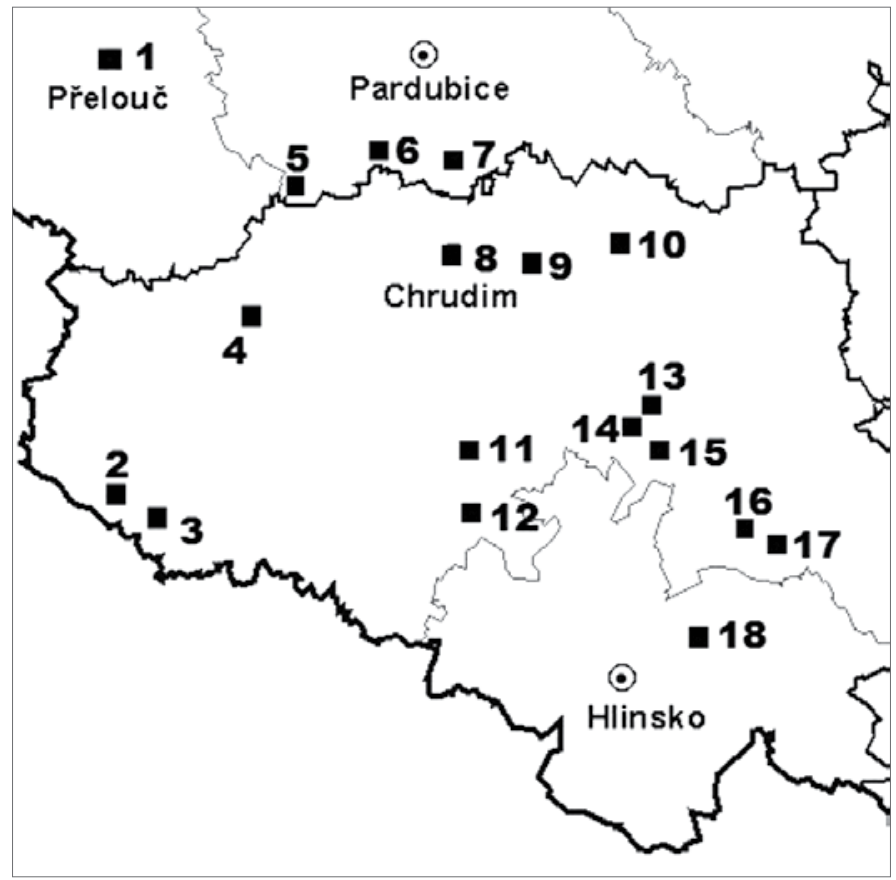

Obr. 1. Chrudimsko a Pardubicko. Mapa s vyznačením zkoumaných církevních staveb a přilehlých hřbitovů. 1 - Přelouč, kostel sv. Jakuba; 2 - Pařížov, kostel sv. Máŕí Magdaleny; 3 - Běstvina, kostel sv. Jana Křtitele; 4 - Kostelec u Heřmanova Městce, kostel sv. Petra a Pavla; 5 - Jezbořice, kostel sv. Václava; 6 - Třebosice, kostel Povýšení sv. Křríže; 7 - Mikulovice, kostel sv. Václava; 8 - Chrudim, kostel Nanebevzetí P. Marie; 9 - Kočí, kostel sv. Bartoloměje; 10 - Hrochův Týnec, kostel sv. Martina; 11 - Práčov, kostel sv. Jakuba; 12 - Nasavrky, kostel sv. Jiljí; 13 - Chrast, místní část Chrašice, kostel sv. Martina; 14 - Chrast, kostel Nejsvětější Trojice; 15 - Podlažice, kostel sv. Markéty; 16 - Skuteč, kostel Nanebevzetí P. Marie; 17 - Lažany, kostel sv. Václava; 18 - Raná, kostel sv. Jakuba. Vypracoval J. Frolík.

Abb. 1. Region Chrudim und Pardubice. Karte mit gekennzeichneten untersuchten Kirchenbauten und daran angrenzenden Friedhöfen. 1 - Přelouč, St. Jakobskirche; 2 Pařížov, Maria Magdalenenkirche; 3 - Běstvina, Johannes-der-Täufer-Kirche; 4 - Kostelec u Heřmanova Městce, Peter- und Paulskirche; 5 - Jezbořice, St. Wenzelskirche; 6 - Třebosice, Kreuzerhöhungskirche; 7 - Mikulovice, St. Wenzelskirche; 8 - Chrudim, Mariä Himmelfahrtskirche; 9 - Kočí, St. Bartholomäuskirche; 10 - Hrochův Týnec, St. Martinskirche; 11 - Práčov, St. Jakobskirche; 12 - Nasavrky, St. Ägidiuskirche; 13 - Chrast, Ortsteil Chrašice, St. Martinskirche; 14 - Chrast, Kirche zur Allerheiligsten Dreifaltigkeit; 15 - Podlažice, St. Margarethenkirche; 16 - Skuteč, Mariä Himmelfahrtskirche; 17 - Lažany, St. Wenzelskirche; 18 - Raná, St. Jakobskirche. Erstellt von J. Frolík.

2006; 2008; Frolík 2014b; Frolík-Musil 2007; 2016; Přelouč, okr. Pardubice, kostel sv. Jakuba - Frolík 2007; Skuteč, okr. Chrudim, kostel N. P. Marie - Frolík 2011; 2013; 2014), vesnické (Běstvina, okr. Chrudim, kostel sv. Jana Křtitele - Frolík 2006; 2006a; Jezbořice, okr. Pardubice, kostel sv. Václava - Frolík-Mácalová-Stránská 2016; Lažany, okr. Chrudim, kostel sv. Václava - Frolík 2007; 2016a; Raná, kostel sv. Jakuba; Třebosice, kostel Povýšení sv. Kříže, oboje okr. Pardubice - Dančová 2014), malá městečka (Hrochův Týnec, okr. Chrudim, kostel sv. Martina Frolík 2009a; Frolík-Švédová 2010; Chrast, kostel Nejsvětější Trojice; Nasavrky, kostel sv. Jiljí, oboje okr. Chrudim - Frolík-Tomášek 2000) a církevní stavby spojené s klášterním prostředím (Podlažice, kostel sv. Markéty; Práčov, kostel sv. Jakuba, oboje okr. Chrudim - Frolík 2002). Celkově se můžeme zabývat 627 prozkoumanými a dokumentovanými hroby. 


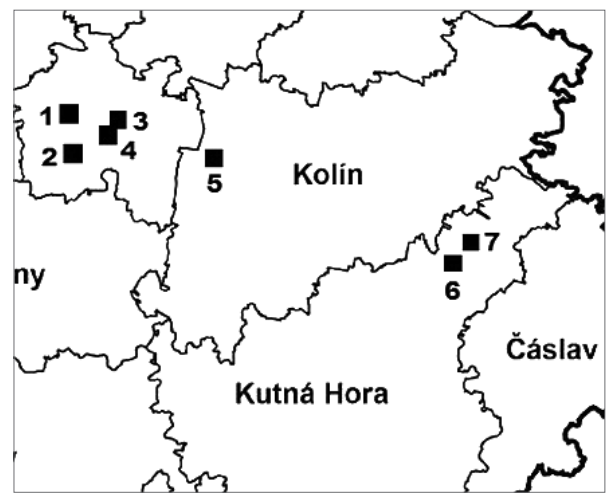

Obr. 2. Kolínsko a Kutnohorsko. Mapa s vyznačením zkoumaných církevních staveb a přilehlých hřbitovů. 1 - Rostoklaty, kostel sv. Martina; 2 - Tismice, kostel Nanebevzetí P. Marie; 3 - Český Brod, kostel sv. Gotharda; 4 - Český Brod, Malechov; 5 - Žabonosy, kostel sv. Václava; 6 - Kutná Hora, zaniklý kostel sv. Jiří; 7 - Kutná Hora - Sedlec, hřbitovní kostel/kostnice Všech Svatých. Vypracoval J. Frolík. Abb. 2. Region Kolín und Kutná Hora. Karte mit gekennzeichneten untersuchten Kirchenbauten und daran angrenzenden Friedhöfen. 1 - Rostoklaty, St. Martinskirche; 2 - Tismice, Mariä Himmelfahrtskirche; 3 - Český Brod, St. Gotthardt-Kirche; 4 - Český Brod, Malechov; 5 - Žane St. Georgskirche; 7 - Kutná Hora - Sedlec, Allerheiligen-Friedhofskirche/Beinhaus. Erstellt von J. Frolík. bonosy, St. Wenzelskirche; 6 - Kutná Hora, verschwunde-

\section{Kolínsko a Kutnohorsko}

Jako určité srovnání může sloužit skupina kostelů zkoumaná z obdobných důvodů na Kolínsku a Kutnohorsku (obr. 2). I zde se hlavní zájem soustředil na stavby datované do románského období na základě dochovaných stavebních částí (Tismice - kostel N. P. Marie, Žabonosy - kostel sv. Václava, oboje okr. Kolín - Frolík 2009a; 2009b; 2010; 2010a; 2010b). Příležitostný charakter měla akce u kostela sv. Martina v Rostoklatech (okr. Kolín), která poskytla vzorek situace u církevní stavby gotického stáŕí (Frolík 2011a). V př́ípadě kostela sv. Gotharda v Českém Brodě byla pouze konstatována př́itomnost hřbitova (hřbitovní vrstvy) bez možnosti provést větší odkryv. Výjimku představuje skupina šesti vrcholně stř̌edověkých hrobů v ulici Prokopa Velikého v Českém Brodě, která není vázána na církevní stavbu (Frolík a kol. v tisku). Záchranný archeologický výzkum pomohl lokalizovat zaniklý gotický kostel sv. Jiří na Kouřimském předměstí Kutné Hory (FrolíkVepřeková 2011). Specifický př́ípad představuje dosud neukončený záchranný archeologický výzkum u hřbitovní kaple/karneru Všech Svatých v Kutné Hoře - Sedlci, který souvisí s odvodněním a statickým zabezpečením objektu. Výzkum zatím odhalil 1006 koster pohřbených v jednotlivých hrobech nebo hrobech hromadných. Podle předběžného vyhodnocení zahrnuje období 13. až 16. století a představuje pozoruhodný vzorek pro studium pohřbívání především ve vrcholném středověku. Vyjma hrobů z Kutné Hory - Sedlce můžeme pracovat s dalšími 128 hroby.

\section{Charakteristika zkoumaných terénů}

Před popisem jednotlivých nalezených situací je třeba učinit několik poznámek. Archeologický výzkum na vrcholně středověkém a raně novověkém hřbitově (nehledě ke hřbitovům užívaným do současnosti) znamená, že značnou část zkoumané mocnosti bude tvořit tzv. hřbitovní vrstva, vzniklá v důsledku hloubení dalších a dalších hrobů na místě, kde se již před tím pohřbívalo. Důsledkem je vznik vrstvy s množstvím ojedinělých lidských kostí a množství torz jednotlivých hrobů a také skupin lidských kostí, u nichž není na první pohled zřejmé, zda jsou v intencionální poloze či nikoliv (obr. 3). Dalším rysem, z hlediska čitelnosti terénní situace problematickým, je jen omezená možnost rozeznat v ploše hrobové jámy. Na rozsah (plochu) hrobové jámy lze zpětně usuzovat z polohy kosterních ostatků v intencionální poloze. O něco lepší bývá čitelnost hran hrobových jam na řezech (obr. 4). Určování vzájemného vztahu různě hluboko uložených kosterních ostatků je často možné jenom na základě jejich př̀krývání se na plánech. Velmi obtížné je potom posouzení vztahu v prŕípadě, že je mezi kostrami pouze malá mezera, ale nejsou navzájem porušeny. Počitat je nutné i se situací, že některá hrobová jáma zasahuje do sondy jenom okrajovou částí, ale vlastní kostra zůstala mimo zkoumanou plochu. Špatná čitelnost rozhraní hrobových jam ještě znamená, že k zásypu hrobu je možno vztáhnout pouze nálezy učiněné při preparaci kostry. Jiné je nutno považovat za obsah výše zmíněné hřbitovní vrstvy. Vlastní hřbitovní vrstva v sobě skrývá z hlediska stratigrafie určitý paradox. Jeví 


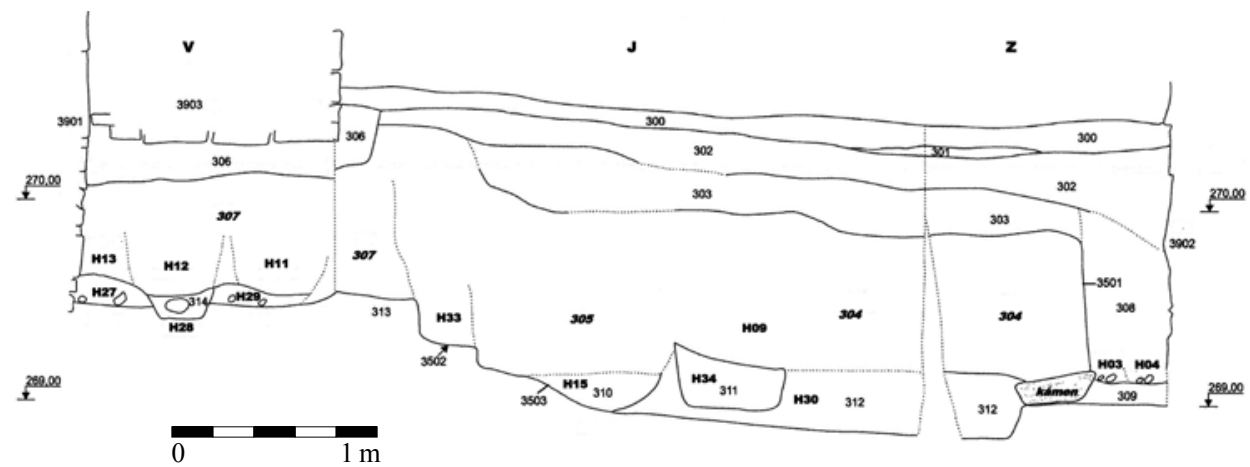

Obr. 3. Jezbořice (okr. Pardubice), hřbitov u kostela sv. Václava, sonda III. Vícenásobná superpozice hrobů 16. až počátku 19. století (H03, H04, H09, H11-H13, H15, H27-H30, H33, H34) v několika horizontech hřbitovní vrstvy $(304,305,307)$. Kresba J. Frolík, digitalizace M. Mácalová.

Abb. 3. Jezbořice (Bezirk Pardubice), Friedhof bei der Wenzelskirche, Sondiergrabung III. Mehrfache Superposition der Gräber des 16. bis Anfang 19. Jhdt. (H03, H04, H09, H11-H13, H15, H27-H30, H33, H34) in mehreren Horizonten der Friedhofsschicht (304, 305, 307). Zeichnung J. Frolík, Digitalisierung M. Mácalová.

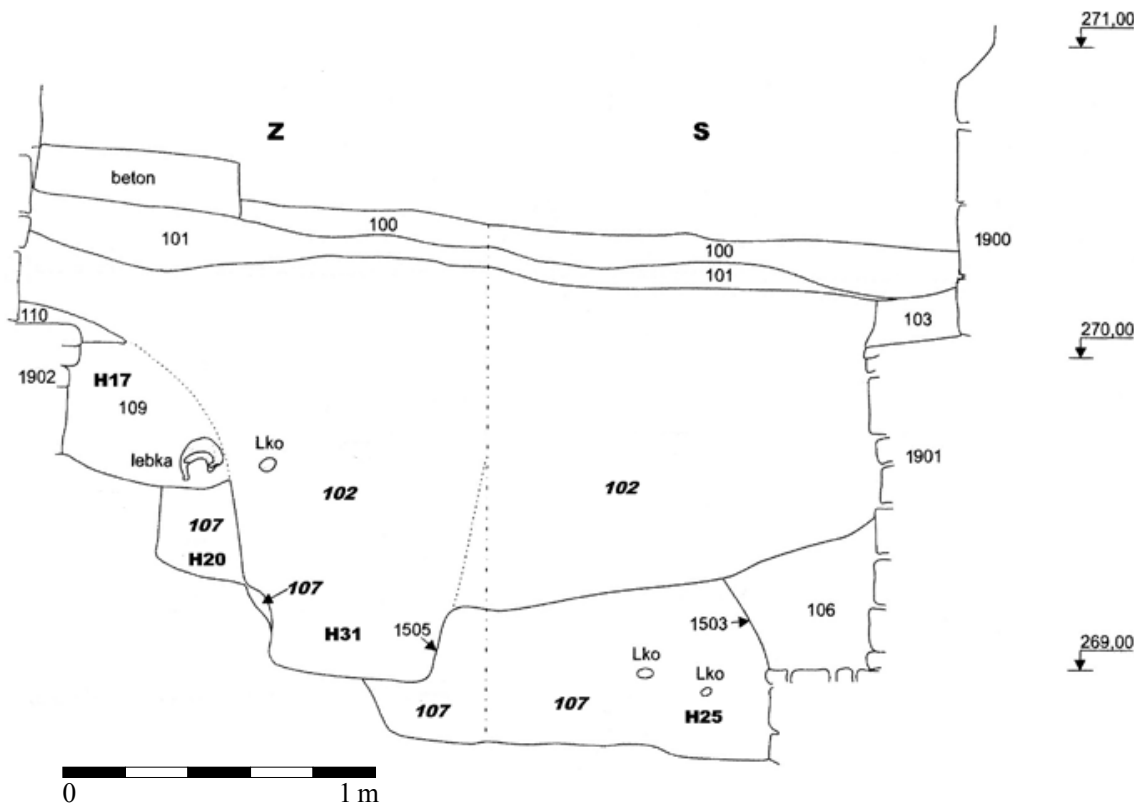

Obr. 4. Jezbořice (okr. Pardubice), hřbitov u kostela sv. Václava, sonda I. Př́íklad hrobové jámy (hrob H31), která se nerýsovala v půdorysu, přestože je výrazná na řezu. Terénní situace sestává ze dvou horizontů hřbitovní vrstvy (102 - po 1550; 107 - před 1550). Kresba J. Frolík, digitalizace M. Mácalová.

Abb. 4. Jezbořice (Bezirk Pardubice), Friedhof bei der Wenzelskirche, Sondiergrabung I. Beispiel für eine Grabgrube (Grab H31), die sich im Grundriss nicht abzeichnete, im Schnitt trotzdem deutlich ist. Die Geländesituation besteht aus zwei Horizonten Friedhofsschicht (102 - nach 1550; 107 - vor 1550). Zeichnung J. Frolík, Digitalisierung M. Mácalová.

se obvykle stejnorodě a může se zároveň nacházet pod zkoumanými hroby, v jejich zásypu a také je překrývat. Uvedený stav je právě důsledkem homogenizace vrstvy a nečitelnosti rozhraní. Ve skutečnosti v sobě hřbitovní vrstva naopak zahrnuje velké množství jednotlivých událostí (převážně hloubení hrobových jam), jejichž úplnému zjištění a správnému popisu brání výše uvedené jevy. 
Popsaná situace také znamená, že jen velmi malé množství nálezů je zjištěno v primární pozici (nejčastěji součásti oděvu zemřelých). Převážná část nálezů je součástí zásypu hrobových jam nebo součástí výše zmíněné hřbitovní vrstvy. Tyto nálezy poskytují pouze datum post quem pro datování hrobu, přičemž skutečná doba uložení zemřelého do hrobu může být mnohem pozdější než svědectví nálezů. Zvlášt' obežretně je nutno posuzovat nálezy mincí, u nichž je obvyklá tendence spojovat je přímočaře s pohřbeným, $v$ jehož hrobové jámě byly nalezeny. Detailně je nutné též zaznamenat vztah kosterních ostatků (nebo v příznivém př́ípadě vztah hrobové jámy) ke zdivům kostela nebo ke vkopům pro tato zdiva. Je to nejčastější možnost, jak hrob při absenci drobných movitých nálezů alespoň rámcově datovat (příklady Frolík 2015a; Frolík-MácalováStránská 2016; Frolík-Stránská-Švédová v tisku).

\section{Hroby}

Zjišsěný hrobový ritus je v naprosté většině případů jednotný. Přetrvává orientace doložená již v raně středověkém období, tj. ve směru východ-západ s hlavou k západu. V mladších etapách (od 16./17. století) etážových pohřebišt' kolem kostelů zjišt'ujeme radiální uspořádání (tj. nejčastěji s hlavou ke kostelu), a to zejména u závěru presbytáře (Běstvina, Lažany - obr. 5). Někde je tato změna orientace jenom dočasná. Na hřbitově u kostela sv. Václava $v$ Jezbořicích byly u jihozápadního nároží kostela nejstarší hroby (10 hrobů) orientovány obvyklým způsobem. Tři stratigraficky mladší hroby (H15, H33, H34) však byly orientovány ve směru sever-jih (hlavou ke kostelu). Datovány jsou do 16. století (obr. 3). Nejmladší etapa pohřbívání (4 hroby), datovaná do období před 18. stoletím, znamená návrat k obvyklé orientaci (Frolík-Mácalová-Stránská 2016). Obdobnou situaci identifikujeme u kostela sv. Václava v Žabonosech, kde k mladší etapě pohřbívání náleží mimo jiné také šest hrobů, orientovaných ve směru sever-jih s hlavou k severu, přičemž i tři hroby severně od kostela (H11, H46, H58) dodržují tuto orientaci, takže pohřbení směřuji ke kostelu nohama. Porovnáme-li polohu hrobů nejstarší etapy s etapou radiál-

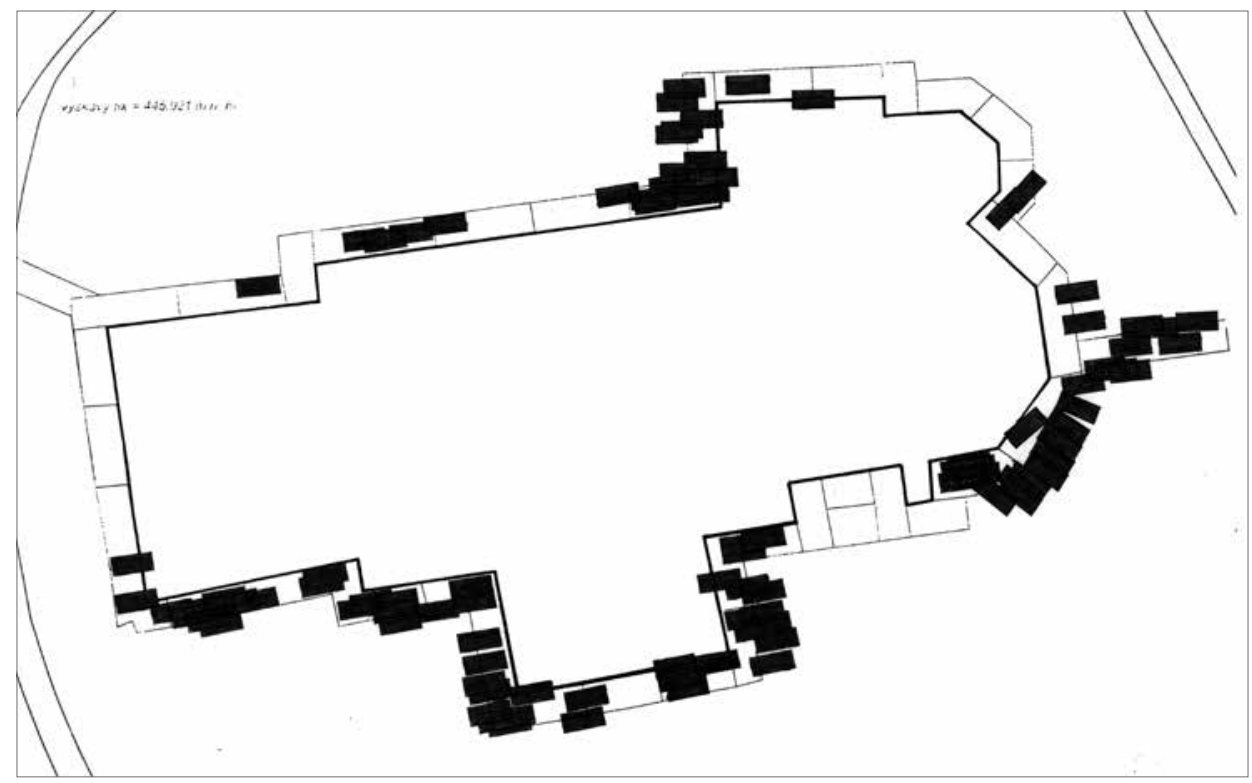

Obr. 5. Lažany (okr. Chrudim), kostel sv. Václava. Obdélníky vyznačují zkoumané hroby; stratigraficky mladší hroby u presbytáře jsou zčásti uspořádány radiálně. Kresba J. Frolík.

Abb. 5. Lažany (Bezirk Chrudim), St. Wenzelskirche. Die Rechtecke kennzeichnen die untersuchten Gräber, die stratigrafisch jüngeren Gräber am Chorraum sind radial angeordnet. Zeichnung J. Frolík. 
ního pohřbívání, je zřejmé, že plocha hřbitova musela být alespoň v pásu kolem kostela zcela přeorganizována a starší pohřby nebyly respektovány. Podobně tomu muselo být při návratu k obvyklé orientaci. Poslední podobnou proměnu uspořádání plochy hřbitova můžeme spojit (podle výskytu nejstarších dat na existujících náhrobcích) s druhou polovinou 19. století. Toto uspořádání, nerespektující starší etapy, přetrvalo na používaných hřbitovech dodnes.

Jiným důvodem odlišné orientace mohly být objekty v ploše hřbitova, které musely hroby respektovat. Tento jev byl zjištěn na zaniklém hřbitově u kostela N. P. Marie v Chrudimi, kde se hroby vyhýbaly torzu starší zděné stavby (Frolík-Musil 2016). Je zřejmé, že hroby musely také respektovat přístup ke kostelu nebo jiné komunikace umožňující pohyb po hřbitově. Zvlášt' nápadné je to na hřbitovech se stísněnou či jednoznačně vymezenou plochou. Př́ikladem může být opět hřbitov u kostela N. P. Marie v Chrudimi, kde bylo zjištěno ,prázdné“ místo (př́ístupová komunikace?) před budovou čp. 57/I, existující již v době užívání hřbitova (Frolík-Musil 2016).

Převažují hrobové jámy s jedním zemřelým. V určitém procentu (méně než $10 \%$ ) identifikujeme pohřby, kdy se v hrobové jámě nachází více zemřelých. Nelze obvykle rozhodnout, zda byli pohřbeni současně (nejčastěji o tom lze uvažovat $u$ hrobů s pohřbem dospělého a dítěte/ dětí) nebo se jednalo o postupné pohřbívání do existující hrobové jámy (obr. 6). Tato varianta předpokládá, že hrob byl nějak označen. Současné pohřbení může doložit pouze specifická poloha kosterních ostatků (Kutná Hora - Sedlec, kostnice, hroby 399 a 400 - obr. 7). Větší počet zemřelých nacházíme pouze v hromadných hrobech (obr. 8), které na hřbitovech v okolí kostelů souvisí s výskytem epidemie, hladomoru nebo válečné události (Kutná Hora - Sedlec, kostnice, hromadné hroby náležející podle stratigrafie nejméně dvěma chronologickým etapám - předběžně je mladší fáze ztotožněna s morovou epidemií 1348-1350 a starší s hladomorem v roce 1318).

Početné vzájemné narušení jednotlivých hrobů značně omezuje možnosti poznat detaily hrobových jam. Obvyklá je prostá obdélná jáma se zaoblenými rohy dále nijak neupravená. Někdy registrujeme na dně mírně prohloubenou obdélnou nebo oválnou část, která je nejspíše svědectvím o použití rakve, nikoliv záměrnou úpravou. Úpravy pomocí dřeva nebo kamenů

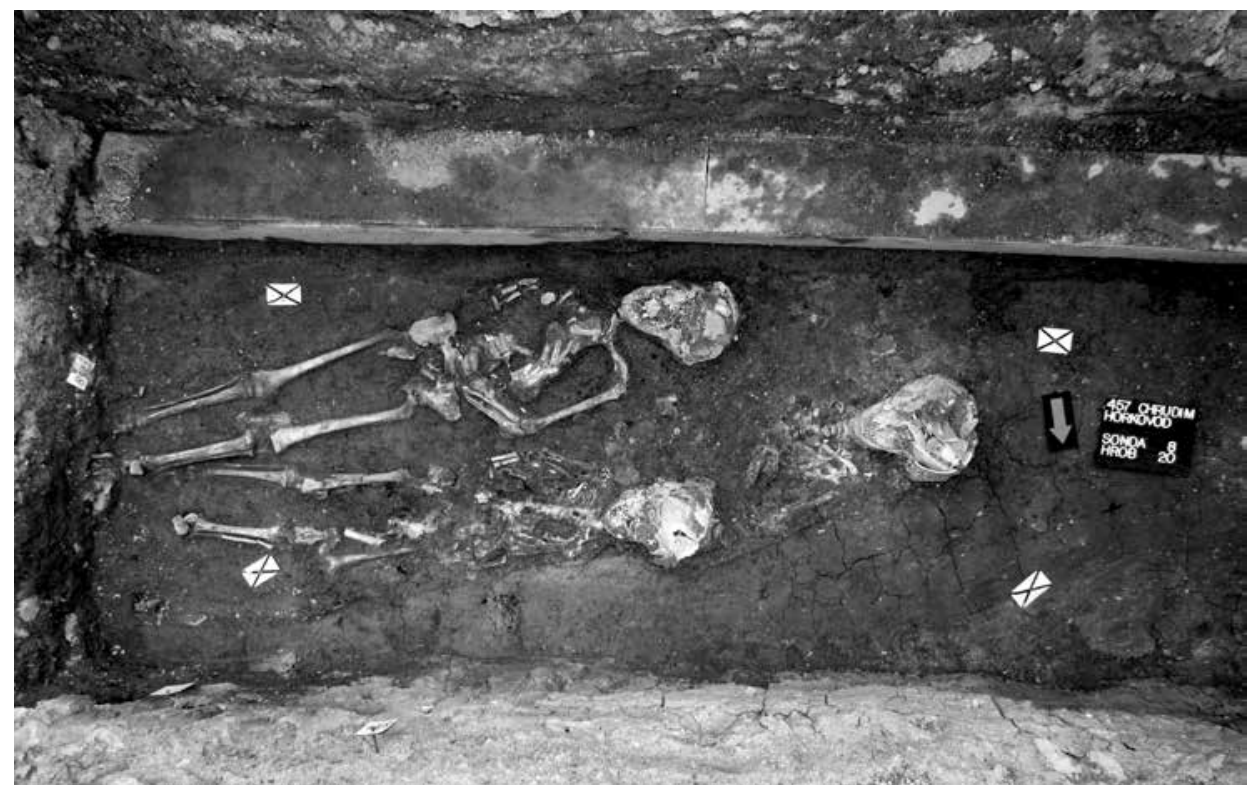

Obr. 6. Chrudim, Školní náměstí, hřbitov u kostela N. P. Marie. Hrob 20/2014 se třemi pohřbenými v jedné hrobové jámě př́ílad „rodinného“ hrobu. Podle Frolík-Musil 2016.

Abb. 6. Chrudim, Schulplatz, Friedhof an der Mariä Himmelfahrtskirche. Grab 20/2014 mit drei in einer Grabgrube beigesetzten Verstorbenen - Beispiel für ein „Familiengrab“. Nach Frolík-Musil 2016. 


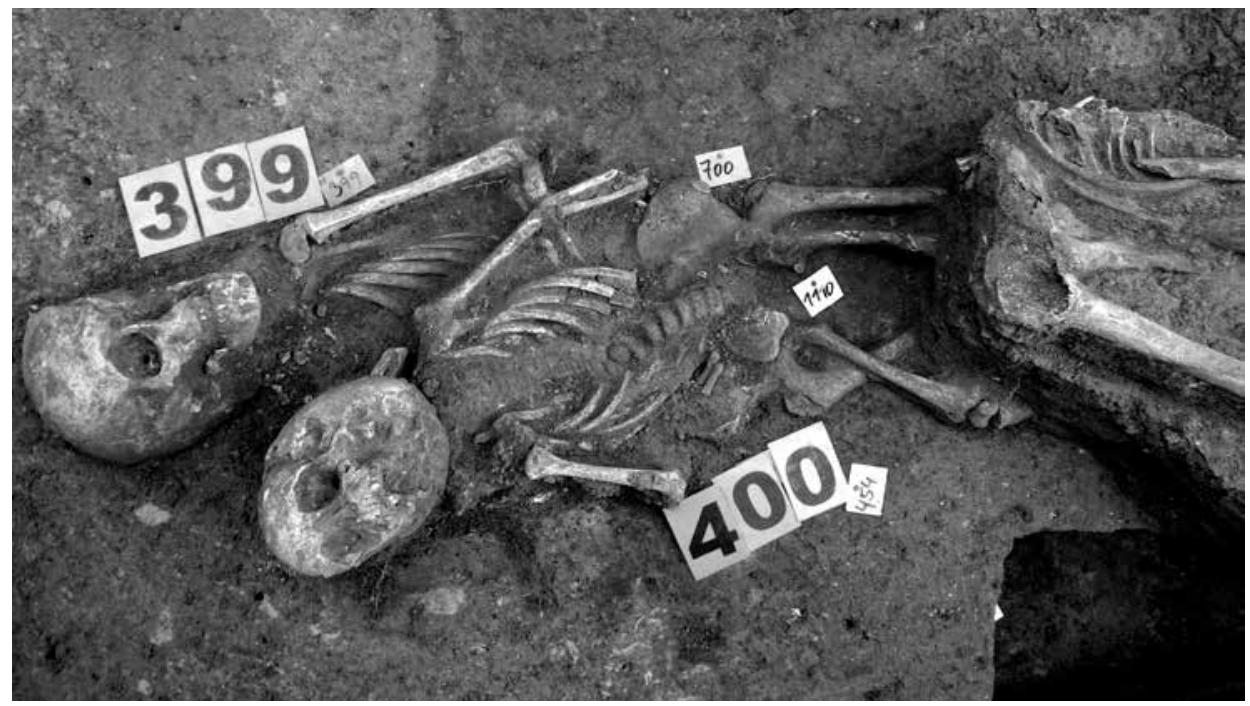

Obr. 7. Kutná Hora - Sedlec, hřbitov u hřbitovní kaple/karneru V̌̌ech Svatých, sektor 6. Hroby/kostry 399 a 400. Poloha nohou dokládá současné uložení zemřelých. Foto P. Kindelman.

Abb. 7. Kutná Hora - Sedlec, Friedhof an der Friedhofskapelle/am Allerheiligenkarner, Sektor 6. Gräber/Skelette 399 und 400. Die Lage der Beine belegt eine gleichzeitige Beisetzung der Verstorbenen. Foto P. Kindelman.

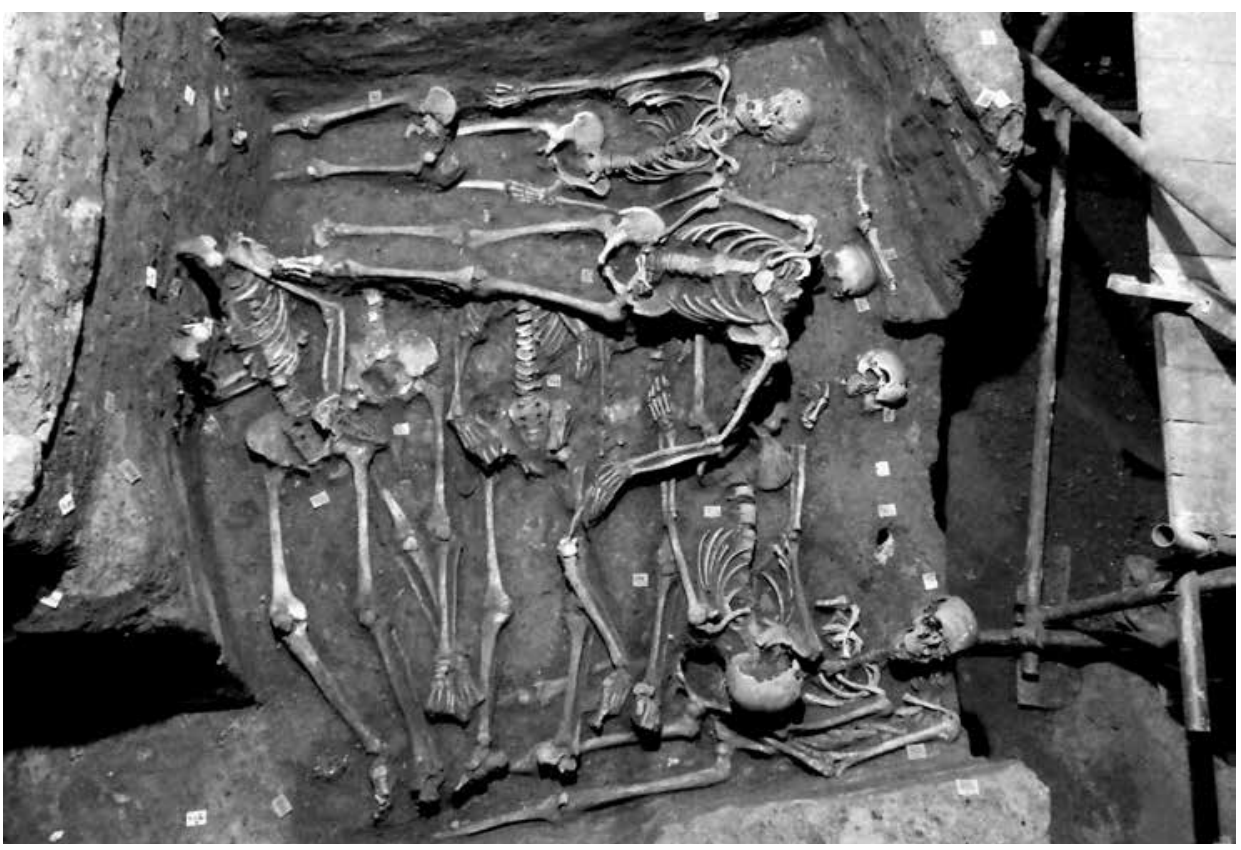

Obr. 8. Kutná Hora - Sedlec, hřbitov u hřbitovní kaple/karneru Všech Svatých, sektor 20. Hromadný hrob. Tř̌i úrovně koster uložených s ohledem na maximální využití prostoru hrobové jámy. Výjimku představuje zemřelý v nejvy̌ší úrovni, poloha na břiše s nepravidelně uloženýma rukama naznačuje, že byl do jámy vhozen. Foto P. Kindelman.

Abb. 8. Kutná Hora - Sedlec, Friedhof an der Friedhofskapelle/am Allerheiligenkarner, Sektor 20. Massengrab. Drei Skelettschichten von im Hinblick auf eine bestmöglichste Nutzung des Grabgrubenraumes beigesetzten Verstorbenen. Eine Ausnahme stellt der Verstorbene in der höchsten Schicht dar, die Bauchlage mit unregelmäßig angeordneten Armen deutet an, dass er in die Grube geworfen wurde. Foto P. Kindelman. 
zjištěny nebyly nebo je nelze (zejména u ojediněle se vyskytujících kamenů) prokázat. Jen malá část pohřbených byla prokazatelně uložena v dřevěné rakvi. Kromě dochovaných pozůstatků dřeva pod a nad kostrou (např. Chrudim, H04 rakev - Frolík-Musil 2016; Jezbořice, H10 - Frolík-Mácalová-Stránská 2016) prokazují užití rakve hřebíky nalezené v původní pozici, tj. vytvářející kolem kostry pomyslný obdélník odpovídající velikosti rakve (např. Jezbořice H05 Frolík-Mácalová-Stránská 2016). Stejně průkazně ukazuje na použití rakve nález kování hran rakve (např. Běstvina, H114; Žabonosy, H45) nebo ozdoby na víku (např. Běstvina, H124 Šilhová-Tribulová 2006; Kučerová 2013). Někdy poukazuje na původní dutý prostor poloha kosterních ostatků (sklopení pánevních kostí - Jezbořice, H27 - Frolík-Mácalová-Stránská 2016). Úprava hrobu ve formě zděné hrobky (kamenné nebo cihlové) se na hřbitovech vně kostelů objevuje až v 17./18. století (Běstvina, Chrast-Chrašice, Jezbořice, Kočí). Část z nich jako označený hrob přetrvala dodnes (Běstvina, Chrast-Chrašice), část během dalšího vývoje zanikla (zaniklo její označení na používaných hřbitovech - Běstvina; zaniklo označení jako důsledek ukončení pohřbívání na hřbitově - Jezbořice, Kočí). Nejčastější je vyzdění vlastní hrobové komory z cihel a následné překrytí několika či jednou kamennou deskou nebo částečné zaklenutí také z cihel.

Nejobvykleji byl zemřelý pohřben na zádech s nataženýma nohama a rukama podél těla. Ruce podél těla se jako téměř jediná pozice objevují do 13. století. Přibližně od 14. století postupně narůstá počet zemřelých s rukama složenýma na břiše nebo na hrudníku. Postupně narůstající počet těchto poloh rukou lze doložit nejlépe na hřbitově u kostela N. P. Marie, kde jejich počet v období 15. a počátku 16. století narůstá (pohřbívání na tomto hřbitově bylo ukončeno

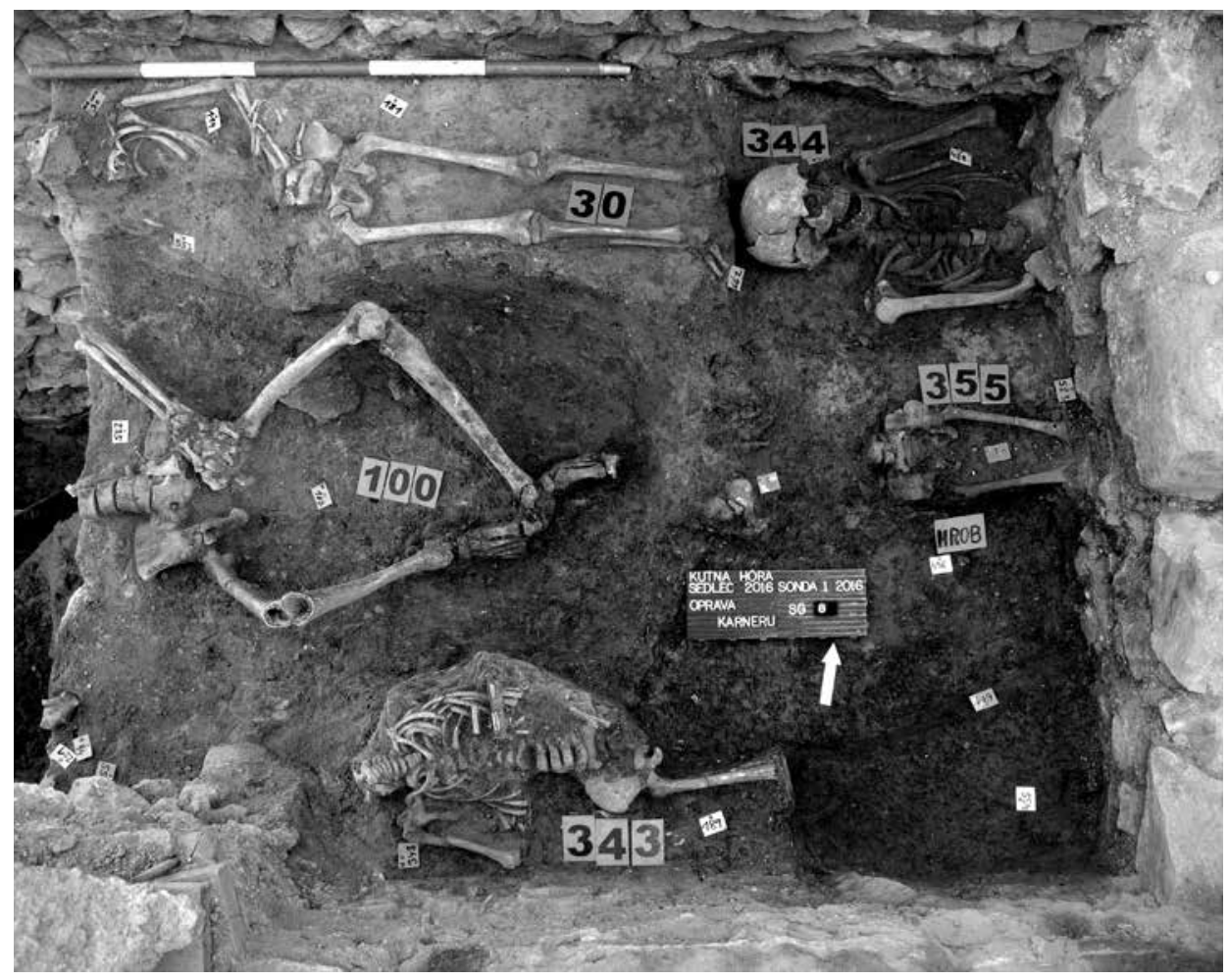

Obr. 9. Kutná Hora - Sedlec, hřbitov u hřbitovní kaple/karneru V̌̌ech Svatých, sektor 8 . Hrob 100 se zemřelým pohřbeným s pokrčenýma nohama s koleny vzhủru. Foto $P$. Kindelman.

Abb. 9. Kutná Hora - Sedlec, Friedhof an der Friedhofskapelle/am Allerheiligenkarner, Sektor 8. Grab 100 mit einem Verstorbenen, der mit angezogenen Beinen und nach oben gestreckten Knien beigesetzt wurde. Foto P. Kindelman. 


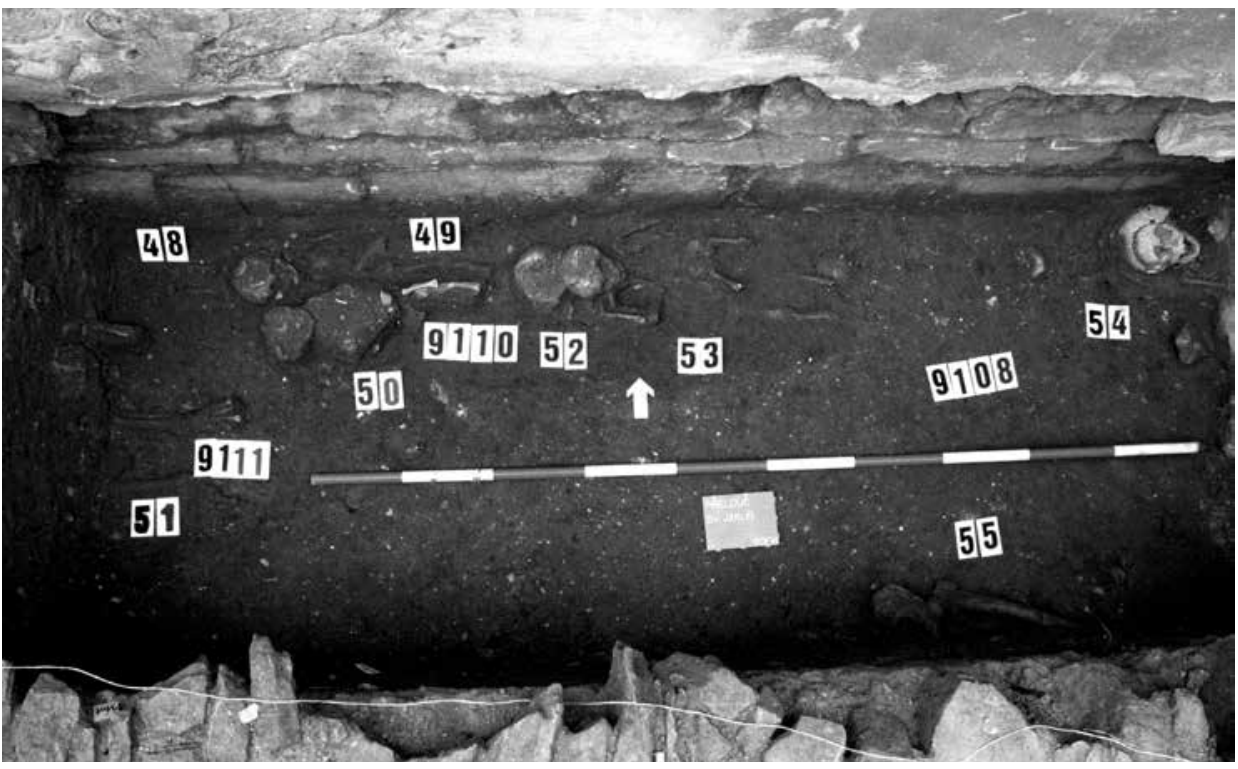

Obr. 10. Přelouč (okr. Pardubice), hřbitov u kostela sv. Jakuba, sonda u jihozápadního nároží s koncentrací dětských pohřbů. Foto J. Frolík.

Abb. 10. Přelouč (Bezirk Pardubice), Friedhof an der St. Jakobskirche, Sondiergrabung an der südwestlichen Ecke mit einer Konzentration von Kinderbestattungen. Foto J. Frolík.

v roce 1518), i když nelze říci, že by naprosto převážila a poloha s nataženýma rukama vymizela (Frolík-Musil 2016). Na hřbitově u kostela sv. Václava v Jezbořicích snad sledujeme vývoj od obliby polohy s rukama složenýma na břiše (ca 1400 až ca 1550) k návratu k poloze s rukama podél těla (Frolík-Mácalová-Stránská 2016). Obdobnou situaci zjišstujeme také u kostela sv. Martina v Chrasti-Chrašicích, kde nejmladší hroby (po 1721) mají polohu rukou podél těla (Frolík 2016a). Stejně byly vyhodnoceny hrobové nálezy u kostela sv. Martina v Hrochově Týnci. Zkoumané hroby (s výjimkou jednoho) náleží ke gotické až barokní etapě hřbitova. Z devíti posuzovatelných jich šest vykazuje ruce natažené podél těla a pouze tř̌i složené do klína či na hrudi. Vyvážené zastoupení má poloha rukou u kostela sv. Bartoloměje v Kočí. Z dvanácti hrobů z období 15. až 19. století, u nichž lze zjistit polohu rukou, jich šest má ruce natažené, pět složených na břiše a jeden na hrudi. K uvedeným př́ikladům je nezbytné dodat, že se jedná o poměrně nevelké vzorky a potvrzení uvedených pozorování mohou přinést pouze další výzkumy většího počtu hrobů s vědomím, že polohu rukou můžeme studovat jenom u menšiny hrobů (na sledovaných pěti hřbitovech je to 54 hrobů ze 139 zkoumaných). Vzácná je nepravidelná poloha nohou, která obvykle souvisí s obtížemi při ukládání zemřelého do hrobu (pokrčené nohy s koleny směřujícími vzhůru nebo chodidla opřená o stěnu hrobové jámy - Kutná Hora - Sedlec, u kostnice - obr. 9).

Specifickou skupinu tvoří hromadné hroby, které (zatím) od kostelů na Chrudimsku či Pardubicku neznáme. Největší skupina byla zachycena během výzkumu u kostnice v Kutné Hoře Sedlci. U západní a východní stěny karneru jich bylo zjištěno nejméně sedmnáct. Mají přibližně čtvercový tvar (rozměry ca $2 \times 2 \mathrm{~m}$ ) a zemřelí do nich byli ukládáni s maximální snahou po využití prostoru, tj. v jedné vrstvě byly kostry uloženy $\mathrm{v}$ orientaci východ-západ a v další v orientaci sever-jih. Rohové partie byly využívány pro uložení malých dětí. Většina nebožtíků byla uložena $\mathrm{v}$ obvyklé poloze, často s rukama zkř́iženýma na břiše či na hrudi. Vyskytnou se i př́ípady svědčící o nedbalém odhození (rozhozené ruce a nohy, vzácně též poloha na břiše obr. 8). V Kutné Hoře spojujeme hloubení většího počtu hromadných hrobů s morovou epidemií 
v letech 1348 až 1350 a méně určitě s hladomorem z roku 1318. Vzájemné narušení hrobových jam dokládá nejméně dvě etapy jejich hloubení odpovídající pravděpodobně dvěma uvedeným datům. Zároveň ukazuje, že hromadné hroby nebyly nejspíše nijak označeny nebo jejich označení nebylo trvanlivé.

Jiné hroby, které mohou vytvářet na hřbitově zvláštní skupinu, jsou hroby dětí. Nejstarším prŕkladem je hřbitov u zaniklého klášterního kostela benediktinského kláštera v Podlažicích, kde se koncentrovaly dětské pohřby blíže k severozápadnímu nároží kostela (Frolík 2004). Hřbitov byl používán nejpozději do roku 1421. Na jižní straně kostela, blíže k jeho jihozápadnímu nároží se soustřed'ovaly u kostela sv. Jakuba v Přelouči (obr. 10 - Frolík 2007). Velká skupina dětských hrobů byla prozkoumána u jihovýchodního nároží kostnice v Kutné Hoře - Sedlci. Někde sledujeme jenom určitou tendenci, kdy je zjištěno více dětských hrobů na jižní straně kostela než na straně severní (Běstvina - Frolík 2007; Jezbořice - Frolík-Mácalová-Stránská 2016). V některých případech však nebylo podobné soustředění či preference určité strany kostela zjištěno (Chrudim - Frolík-Musil 2016). Zde je třeba zohlednit fakt, že prozkoumaná plocha nebyla dostatečně velká. Celkový závěr je prozatím neurčitý. Na některých hřbitovech byly jejich části vymezeny pro přednostní ukládání dětských zemřelých, ale výběr místa byl ve vztahu ke kostelu různý. Jakými kritérii se výběr řídil, nevíme.

Nejednoznačné svědectví přinášejí archeologické výzkumy v otázce označování jednotlivých hrobů. Ikonografické prameny (např̀. Ariès 2000, 325-334; Flüeler-Flüeler 1992, 476,

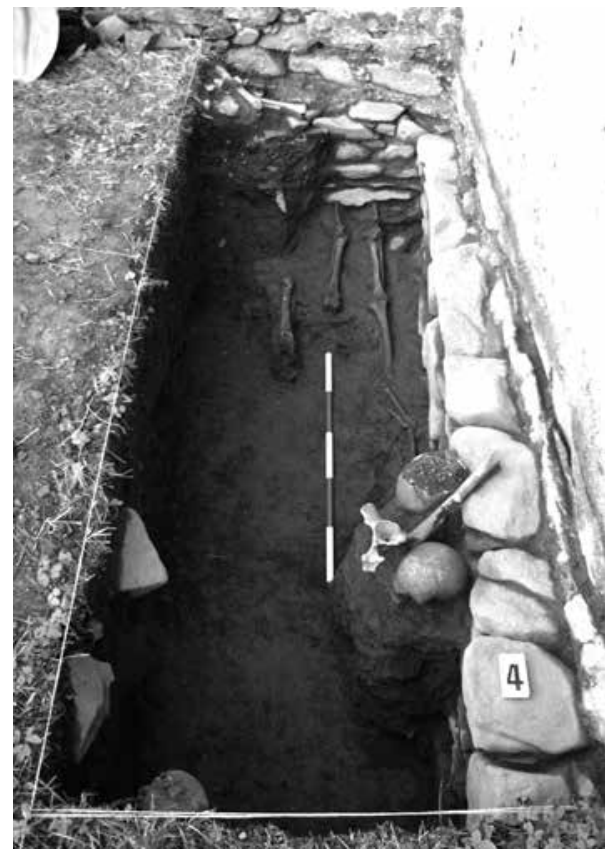

Obr. 11. Lažany (okr. Chrudim), hřbitov u kostela sv. Václava, sonda 4. V úrovni základového ústupku leží dvě skupiny lidských kostí (novověk, označené jako hroby H01 a H04), přenesené/pohozené sem ze starších hrobů, pod nimi starší hroby (středověk, H02 a H03). Foto J. Frolík.

Abb. 11. Lažany (Bezirk Chrudim), Friedhof an der St. Wenzelskirche, Sondiergrabung 4. Auf Ebene des Fundamentsockels liegen zwei Gruppen menschlicher Knochen (Neuzeit, gekennzeichnet als Gräber H01 und H04), die aus älteren Gräbern dorthin umgebettet/geworfen wurden (Mittelalter, H02 und H03). Foto J. Frolík. 478) ukazují, že alespoň část hrobů byla označována nejčastěji zřejmě jednoduchým dřevěným kř́ižem. Archeologické stopy podobných označení však až na několik málo výjimek neznáme. Vzácně se objevují hroby překryté nezdobenými kamennými deskami (Běstvina, Podlažice, Žabonosy). Jejich užívání ovšem spojujeme s obdobím starším než 14. století (Hanuliak 1979). Důvod, proč byl konkrétní hrob takto označen, nedovedeme určit. Zemřelí uložení v těchto hrobech se svou výbavou (či spíše její absencí) neodlišují od jiných pohřbů na lokalitě. Od 16. století zjišt'ujeme výskyt bohatě zdobených náhrobních desek (např. Bítovany, Chrast-Chrašice, Morašice, Rosice - Chytil 1900, 2-3, 28-31, 171-172, 185-186), dnes převážně přemístěných do druhotných poloh (obvykle na stěnách kostela nebo na hřbitovní zdi) v důsledku památkových úprav v 19. a 20. století. Př́ikladem může být kostel sv. Archanděla Michaela v Chrudimi, postavený na nově zřízeném hřbitově (v roce 1518) v letech 1520-1530 (Chytil 1900, 80). Nejstarší datovaný kus ze souboru více než čtyřiceti náhrobků a jejich zlomků je $\mathrm{z}$ roku 1562, nejmladší z roku 1610 (Chytil 1900, 92-96). V intaktní poloze nebyl (zatím?) podobný náhrobek objeven. Označení většiny hrobů, pokud nějaké bylo, bylo zřejmě jednoduché a netrvanlivé (ze dřeva? prostý rov?). Dokládá ho ukládání více zemřelých do jedné hrobové jámy. Ta musela být označena natolik přesně, aby bylo při jejím opětovném otevření 


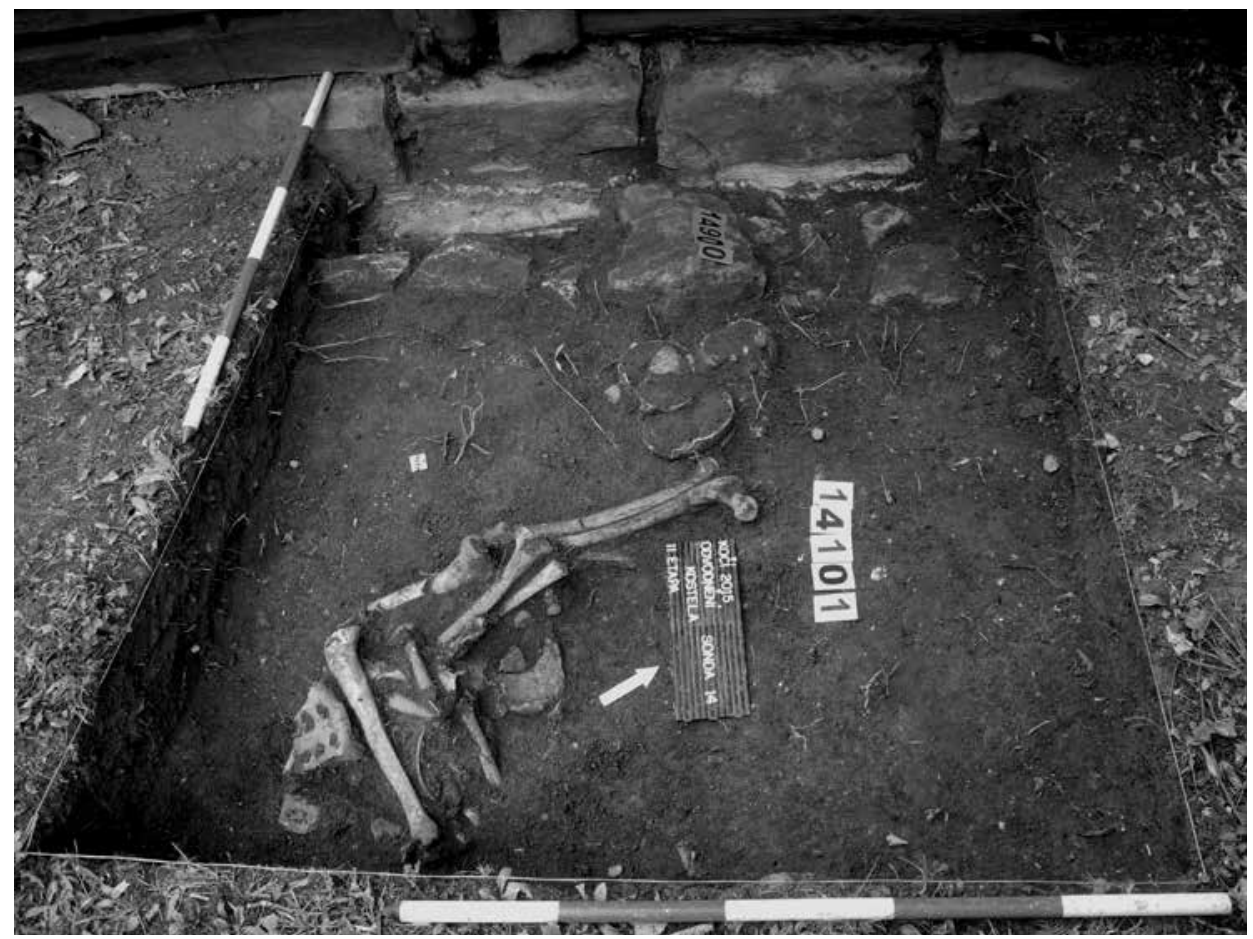

Obr. 12. Kočí (okr. Chrudim), hřbitov u kostela sv. Bartoloměje, sonda 14. Lidské kosti druhotně uložené/pohozené u hřbitovní zdi. Foto P. Kindelman.

Abb. 12. Kočí (Bezirk Chrudim), Friedhof bei der St. Bartholomäuskirche, Sondiergrabung 14. An der Friedhofsmauer sekundär beigesetzte/hingeworfene menschliche Knochen. Foto P. Kindelman.

možné přidat dalšího zemřelého těsně k předchozímu. Na straně druhé ukazuje hloubení nových hrobových jam bez respektu ke starším hrobům a jejich částečné/převážné narušení, že některé hroby určitě označeny nebyly. Jako určitý model je možné formulovat hypotézu o konkrétních hrobových místech užívaných určitou rodinou, která byla označena. V případě, že tato rodina místo přestala používat (odstěhovala se, vymřela), označení hrobu začas zaniklo (pokud nějaké bylo) a místo se „uvolnilo“ pro nové používání. Tedy model podobný dnešnímu, ovšem s tím, že rozložení hrobů (hrobových míst) nebylo stabilní. Jinak by nemohlo docházet k jenom částečnému překrývání a narušování starších hrobů pohřby novými.

Při hloubení nových hrobových jam docházelo k narušení či úplnému odstranění starších kosterních ostatků. Zacházení s nimi probíhalo několika způsoby. Zřejmě nejčastější formou je jejich přesun do hřbitovní vrstvy, tj. jejich přítomnosti zřejmě nebyla věnována větší pozornost. Zčásti se dostaly do zásypu nové hrobové jámy, zčásti zřejmě do povrchových vrstev hřbitova. Jenom ojediněle zjišt'ujeme shrnutí starších kosterních ostatků ke kraji hrobové jámy (Žabonosy, H31). Podobné rozlišení je však možné pouze v př́ípadě jednoznačně odlišitelné hrobové jámy. V př́ípadě etážového pohřbívání bez rozeznatelných hran hrobových jam nelze obvykle určit, zda se jedná o kosti záměrně shrnuté při hloubení nové hrobové jámy nebo nahodile vzniklý shluk kostí ze hřbitovní vrstvy. Někdy zjišt'ujeme vyzvednutí nalezených kostí a jejich záměrné přemístění/pohození na jiném místě hřbitova. Několik takových případů bylo zjištěno u kostela sv. Václava v Lažanech, kde byly kosti přesouvány na severní stranu kostela, a to v období, kdy přestala být část hřbitova severně od kostela používána (pravděpodobně v 19. století), a jediné kosterní ostatky z tohoto období představují druhotně sem přemístěné (odhozené) kosti (obr. 11). 


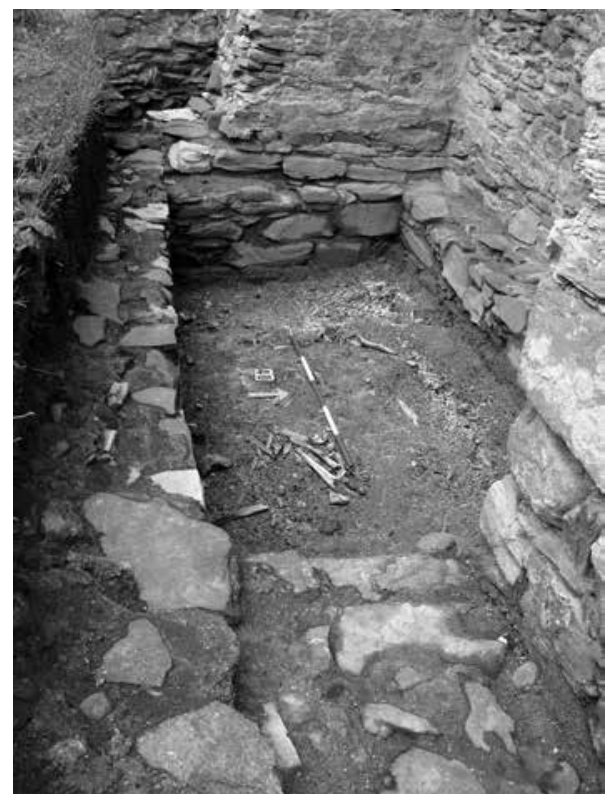

Obr. 13. Lažany (okr. Chrudim), kostel sv. Václava. Zaniklá kostnice na jižní straně presbytáře, tvořící původně integrální část kostela z 2. poloviny 14. století, během výzkumu. Foto J. Frolík.

Abb. 13. Lažany (Bezirk Chrudim), St. Wenzelskirche. Verschwundenes Beinhaus an der Südseite des Chorraums, das ursprünglich integrierter Bestandteil der Kirche aus der zweiten Hälfte des 14. Jahrhunderts war, während der Grabung. Foto J. Frolík.
Jiným vhodným místem mohla být okrajová část hřbitova, jako je tomu u kostela sv. Bartoloměje v Kočí, kde byly kosti ukládány/ odhazovány ke hřbitovní zdi (obr. 12). Předpokládat musíme také neregulovaný zánik kostí ponechaných na povrchu (a jistě nikoliv v malém množství).

Jiným způsobem ukládání lidských kostí byly kostnice. Nejlépe poznanou ukázkou je kostnice u kostela sv. Václava v Lažanech. Byla postavena jako integrální součást stavby ve druhé polovině 14 . století. Tvořila jí nevelká obdélná prostora o rozměrech $1,5 \times 3,1 \mathrm{~m}$ na jižní straně presbytáře, zahloubená $0,9-1,0 \mathrm{~m}$ pod úroveň koruny základového zdiva kostela (obr. 13). Výzkum ukázal, že kosti do ní byly zřejmě účelně skládány s cílem co nejlépe využít omezený prostor. Pokud již nestačil, byly kosti záměrně (s)páleny. Na povrch shořelých kostí byly ukládány kosti nové. Kostnice sloužila svému účelu určitě ve 14. století a zrejmě také během století patnáctého. Pak byla zbořena. Do jejího interiéru se kromě kostí dostala také část hrobové výbavy (miniaturní ostruha, svatojakubská mušle, přezka, tyto předměty nezáměrně) a také soubor nejméně 19 nádob, u něhož se uvažuje o jeho využívání při liturgických obřadech a následném záměrném uložení do kostnice (Kloužková a kol. 2014). Částečně byl podobný objekt prozkoumán na severní straně presbytáře kostela sv. Jakuba v Přelouči (obr. 14). I zde souvisel s gotickou fází kostela, která rozšíríila původní románskou svatyni ve 14. století. Také zde byly kosti páleny (další podobný nález kostnice s částečně spálenými lidskými kostmi je autorovi znám od zaniklého kostela sv. Jana Krrtitele v Lysé nad Labem - Lutovský a kol. 2012, 1034-1035).

Jen málo přímých poznatků poskytly provedené výzkumy v otázce hranic popisovaných hřbitovů. Základním důvodem je fakt, že se archeologický výzkum odehrává obvykle v těsném sousedství kostela a jen málokdy také v ploše hřbitova (Běstvina) a jen výjimečně se dotkne jeho dnešního okraje (Lažany). Někde je plocha hřbitova dána terénní konfigurací. V případě, že jsou kostel a hřbitov umístěny na terénním výběžku, vymezují jeho rozsah na větší části obvodu terénní hrana a na ni navazující svah (Běstvina, Chrast-Chrašice, Kostelec u Heřmanova Městce). Proměnlivá hranice mohla být pouze směrem $\mathrm{k}$ terénu, $\mathrm{z}$ něhož výběžek vycházel. Do této plochy se také hřbitov rozšiřil v novověku, obvykle až v 19. století, pokud již plošně nedostačoval (Běstvina, Chrast-Chrašice). Městskými hradbami a městskými objekty byl vymezen hřbitov u kostela N. P. Marie v Chrudimi, který je výjimečný i tím, že známe přesně dobu jeho používání (1338-1518), což dovoluje alespoň rámcově stanovit počet osob, které zde mohly být pohřbeny (Frolík-Musil 2016). Čísla se zdají být vysoká (8 000 až 10000 zemřelých při asi 1500 na něm pohřbívajících obyvatelích tehdejší Chrudimi). Obdobný odhad byl vypracován pro hřbitov u kostela sv. Václava v Lažanech. Dnešní hřbitov je vymezen kamennou zdí, viditelně opakovaně opravovanou a přezdívanou, ale v podzemní části pocházející již ze 14. století (Frolík 2007). Průběh zdi a tvar hřbitova naznačuje možnost jeho rozšíření jižním směrem před rokem 1839 (obr. 15). Archeologicky se tuto skutečnost nepodařilo (zatím) ani potvrdit a ani vyvrátit. Pokud provedeme stejný odhad počtu pohřbených, dospějeme k číslu asi 3000 . Komunita, která 


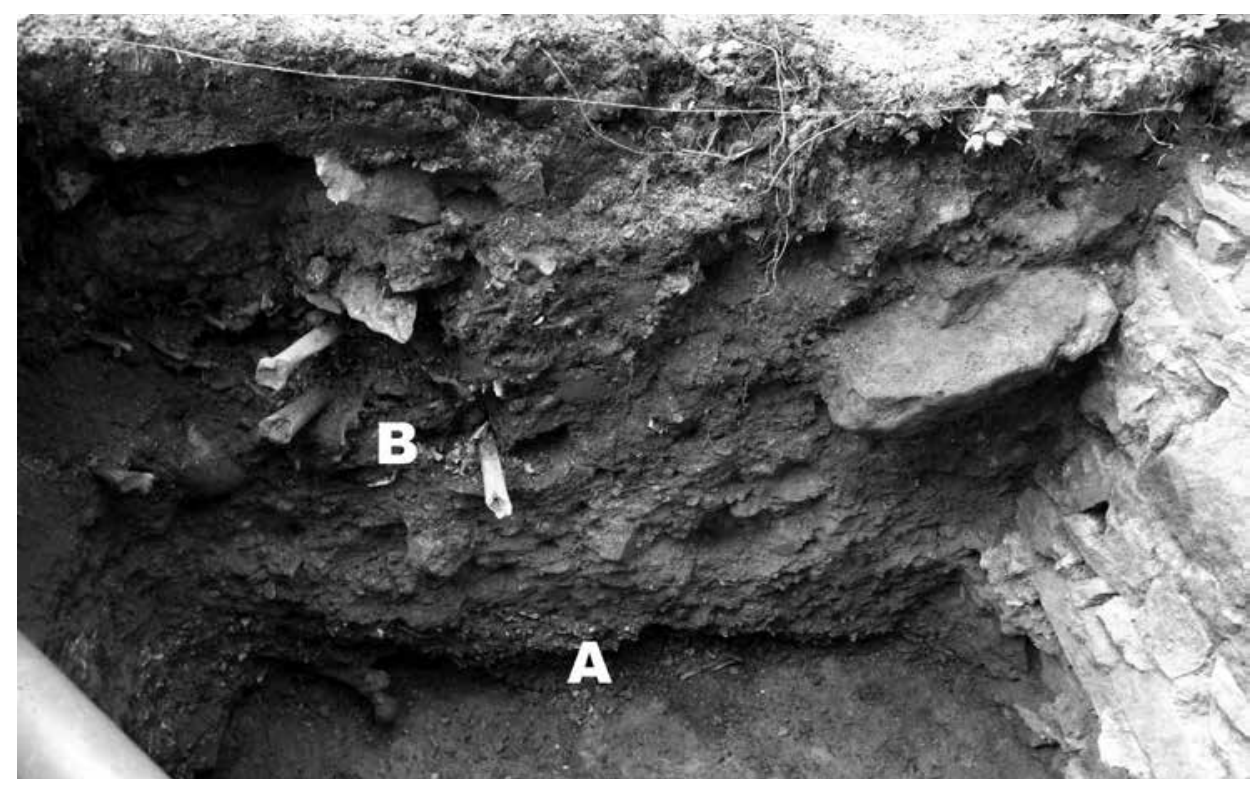

Obr. 14. Přelouč (okr. Pardubice), kostel sv. Jakuba. Zaniklá kostnice na severní straně presbytáře, pohled do jejího zásypu. Dole vrstva spálených lidských kostí(A), nahoře promíšená vrstva spálených i nespálených lidských kostí (B). Foto J. Frolík. Abb. 14. Přelouč (Bezirk Pardubice), St. Jakobskirche. Verschwundenes Beinhaus an der Nordseite des Chorraums, Blick auf seine Verfüllung. Unten eine Schicht verbrannter menschlicher Knochen (A), oben eine vermengte Schicht aus verbrannten und nicht verbrannten menschlichen Knochen (B). Foto J. Frolík.

zde pohřbívala, měla velikost asi 150 až 200 osob (vlastní Lažany a několik nejbližších obcí). Části hřbitova nebyly přitom po delší dobu vůbec využívány. Na dnes prázdné severní polovině hřbitova se pravděpodobně nepohřbívá od roku 1835 (Frolík 2016a).

Jen málo poznatků bylo získáno o neregulérních pohřbech a pohřebištích mimo hřbitovy u kostelů. Ze sledované oblasti neznáme pohřby v souvislosti s popravišti nebo hroby obětí válečných konfliktů (teoreticky by $\mathrm{k}$ nim mohly náležet některé hromadné hroby ze hřbitova v Kutné Hoře - Sedlci). Přri výzkumu v Nasavrkách (okr. Chrudim) byl prozkoumán hrob situovaný vně hřbitovní zdi s regulérně uloženým zemřelým (ruce zkřížené na břiše). Datován byl do 18. století (Frolík-Tomášek 2000). Nálezová situace nedovoluje určit příčinu, která vedla k pohřbu mimo regulérní plochu hřbitova (jinověrec? sebevrah?). Skupina šesti hrobů ze druhé poloviny 15. století byla prozkoumána na okraji Kouřimského předměstí Českého Brodu v poloze Malechov, při silnici spojující toto město s Kouřimí a Kolínem. Situování hřbitůvku a antropologická analýza vedly k interpretaci pohřbených jako lidí žijících na okraji tehdejší společnosti (tuláci, žebráci, honáci dobytka aj. - Frolík a kol. v tisku).

\section{Závěr}

Záchranné archeologické výzkumy u kostelů na Chrudimsku, Pardubicku, Kolínsku a v Kutné Hoře dovolují nahlédnout do pohřebních zvyklostí v uvedené oblasti v období 14. až 19. století (a zčásti i předtím). Celkem 755 dokumentovaných hrobů (plus 1006 hrobů neukončeného výzkumu v Kutné Hoře - Sedlci) ukazuje, že se v obecné rovině zvyklosti při nakládání s těly zemřelých nelišily od zjištění z jiných oblastí (Unger 2000; 2002). Ani tak velký počet prozkoumaných hrobů však zatím nedostačuje ke sledování místních rozdílů nebo k jednoznačné interpretaci některých jevů. Podmínkou pro vyplnění této mezery jsou další výzkumy a také detailní publikace nálezů z jednotlivých hřbitovů. 


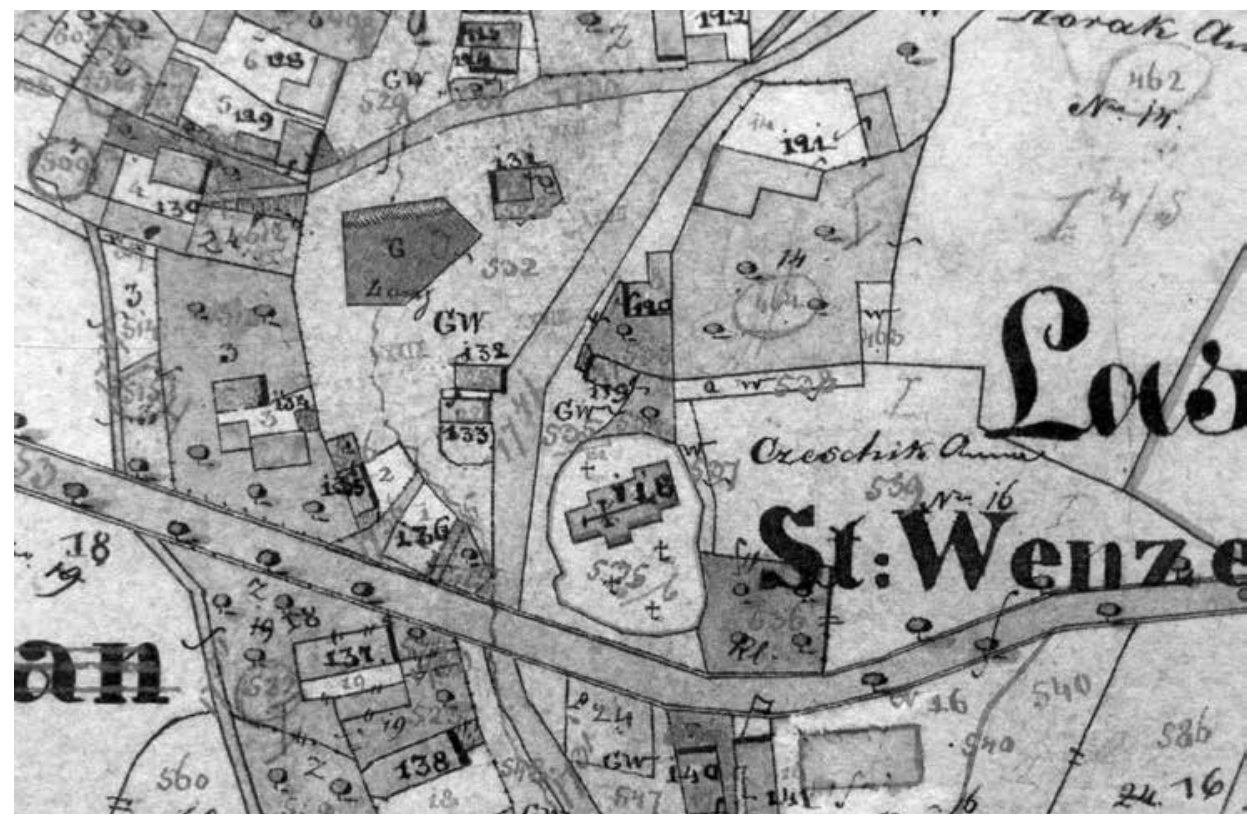

Obr. 15. Lažany (okr. Chrudim), kostel sv. Václava se hřbitovem na mapě stabilního katastru z roku 1839. Tvar vymezení hřbitova kamennou zdí naznačuje jeho dodatečné rozšíření jižním směrem, které se však nepodařilo archeologicky potvrdit. Podle Ebel-Václavík-Šeda 2004.

Abb. 15. Lažany (Bezirk Chrudim), St. Wenzelskirche mit Friedhof auf einer Karte des Stabilen Katasters aus dem Jahr 1839. Die Form der Eingrenzung des Friedhofs durch eine Steinmauer deutet seine nachträgliche Vergrößerung nach Süden hin an, die archäologisch jedoch nicht bestätigt werden konnte. Nach Ebel-Václavík-Šeda 2004.

Článek vznikl jako součást projektu 14-36938G „Středověká populace v centru a na venkově. Archeologie, bioarcheologie a genetika na pohřebištích Pražského hradu, středních a východních Čech“ podporovaného Grantovou agenturou ČR.

\section{Literatura}

ARIÈS, P., 2000: Dějiny smrti I. Praha.

DANČOVÁ, V., 2014: Záchranný archeologický výzkum u kostela Povýšení sv. Kříže v Třebosicích (okr. Pardubice), Chrudimský vlastivědný sborník 18, 197-226.

EBEL, M.-VÁCLAVÍK, F. R.-ŠEDA, B., 2004: Stavebně-historický průzkum kostela sv. Václava v Lažanech (CR), Pardubice, rkp. ulož. na pracovišti Pražský hrad, Oddělení záchranných výzkumů Archeologického ústavu AV ČR, Praha, v. v. i.

FLÜELER, M.-FLÜELER, N., 1992: Stadluft, Hirsebrei und Bettelmönch. Die Stadt um 1300. Stuttgart.

FROLÍK, J., 2002: Záchranný archeologický výzkum u kostela sv. Jakuba v Práčově (obec Svídnice, okr. Chrudim) v roce 2001 - Salvage excavations by St. James's church at Práčov, community Svídnice, distrikt of Chrudim, in 2001, ZMHK 28, 232-239.

- 2004: Záchranný výzkum na místě zaniklého benediktinského kláštera v Podlažicích (okr. Chrudim) Rettungsgrabung auf dem Platz des ehemaligen Benediktenklosters in Podlažice (Bez. Chrudim), Zprávy ČAS - Supplément 56, 33-34.

- 2005: Archeologický výzkum na klášteřišti u kostela sv. Markéty v Podlažicích, Muzejní a vlastivědná práce / Časopis Společnosti prátel starožitností 43/113, 238-239.

- 2006: Archeologické výzkumy na Chrudimsku v roce 2005 - Archäologische Forschung in der Umgebung von Chrudim im J. 2005, Zprávy ČAS - Supplément 64, 33-36.

- 2006a: Záchranný výzkum u kostela sv. Jana Křtitele v Běstvině na Chrudimsku, Chrudimské vlastivědné listy 15 , č. 3, 6-7. 
- 2007: Záchranné výzkumy u středověkých kostelů na Chrudimsku a Pardubicku - Rettungsgrabungen bei einigen mittelalterlichen Kirchen in der Umgebung von Chrudim und Pardubice, Zprávy ČAS Supplément 68, 48-49.

- 2008: Hrad v Chrudimi? (Archeologický výzkum na Školním náměstí a v Komenského ulici v letech 2004-2006) - Eine Burg in Chrudim? (Die archäologische Grabung auf dem Školní-Platz und in der Komenského-Gasse 2004-2006), CB 11, 553-584.

- 2009: Zpráva o záchranném archeologickém výzkumu provedeném na lokalitě Hrochův Týnec (okr. Chrudim) - akce: Oprava opěrné zdi u kostela sv. Martina (smlouva 790077), ulož. v archivu ARÚ AV ČR, Praha, v. v. i., čj. 11843/09.

- 2009a: Zpráva o záchranném archeologickém výzkumu provedeném na lokalitě Žabonosy (okr. Kolín) akce: Celková rekonstrukce a zpř́istupnění kostela sv. Václava (smlouva 790089), 1. etapa prací, ulož. v archivu ARÚ AV ČR, Praha, v. v. i., čj. 11842/09.

- 2009b: Zpráva o záchranném archeologickém výzkumu provedeném na lokalitě Tismice (okr. Kolín) akce: kostel Nanebevzetí P. Marie, rekonstrukce a zpřístupnění kostela (smlouva 790088), 1. etapa prací, ulož. v archivu ARÚ AV ČR, Praha, v. v. i., čj. 12070/09.

- 2010: Záchranné archeologické výzkumy u kostelů v Tismicích a v Žabonosech (okr. Kolín) - Archäologische Rettungsgrabungen bei den Kirchen zu Tismice und Žabonosy (Bez. Kolín), Zprávy ČAS Supplément 78, 41-42.

- 2010a: Zpráva o záchranném archeologickém výzkumu provedeném na lokalitě Žabonosy (okr. Kolín) akce: celková rekonstrukce a zpř́ístupnění kostela sv. Václava (smlouva 790115) - 2. etapa prací, ulož. v archivu ARÚ AV ČR, Praha, v. v. i.

- 2010b: Zpráva o záchranném archeologickém výzkumu provedeném na lokalitě Tismice (okr. Kolín) akce: kostel Nanebevzetí P. Marie, rekonstrukce a zpřístupnění kostela (smlouva 790116) - 2. etapa prací, ulož. v archivu ARÚ AV ČR, Praha, v. v. i.

- 2011: Počátky pravěkého a středověkého osídlení Skutečska - The oldest trace of humans in the Skuteč area - Die Spuren der urzeitlichen Besiedlung in der Umgebung von Skuteč. In: Voráček, E. a kol., Dějiny Skutče. Skuteč, 9-20, 366-368, 393, 406, 415.

- 2011a: Zpráva o záchranném archeologickém výzkumu provedeném na lokalitě Rostoklaty (okr. Kolín) akce: Kostel sv. Martina - odvodnění (dohoda 711034), ulož. v archivu ARÚ AV ČR, Praha, v. v. i., sign. TX-2011-2676.

- 2012: Zpráva o záchranném archeologickém výzkumu provedeném na lokalitě Kostelec u Heřmanova Městce, kostel sv. Petra a Pavla. Akce: zjištovací sondy (dohoda 711098), ulož. v archivu ARÚ AV ČR, Praha, v. v. i., sign. TX-2012-2437.

- 2013: Záchranný archeologický výzkum u kostela Nanebevzetí Panny Marie ve Skutči (př́spěvek archeologie k počátkům Skutče), Chrudimský vlastivědný sborník 17, 215-262.

- 2014: Nálezová zpráva o záchranném archeologickém výzkumu provedeném na lokalitě Skuteč - kostel N. P. Marie. Akce: odvodnění (smlouva 750116), ulož. v archivu ARÚ AV ČR, Praha, v. v. i., 2014, sign. TX-2014-5075.

- 2014a: Zpráva o záchranném archeologickém výzkumu provedeném na lokalitě Kočí (okr. Chrudim), kostel sv. Bartoloměje. Akce: odvodnění terénu při patě obvodového zdiva, I. etapa (dohoda 714052). IDAV 44707, ulož. v archivu ARÚ AV ČR, Praha, v. v. i., 2014, sign. TX-2014-5194.

- 2014b: Zpráva o záchranném archeologickém výzkumu provedeném na lokalitě Chrudim (okr. Chrudim), kostel Nanebevzetí Panny Marie. Akce: deštové svody (dohoda 714053). IDAV 49440, ulož. v archivu ARÚ AV ČR, Praha, v. v. i.

- 2015: Záchranný archeologický výzkum u kostela sv. Bartoloměje v Kočí (okr. Chrudim) - Archäologische Rettunggrabungen bei St. Bartholomäuskirche in Kočí (Bez. Chrudim), Zprávy ČAS - Supplément 97, 52-53.

- 2015a: Záchranný archeologický výzkum u kostela sv. Martina v Chrasti-Chrašicích (okr. Chrudim) Rescue Archaeological Survey at St. Martin Church in Chrast-Chrašice (District Chrudim), Východočeský sborník historický 28, 5-42.

- 2015b: Zpráva o záchranném archeologickém výzkumu provedeném na lokalitě Kočí (okr. Chrudim), kostel sv. Bartoloměje. Akce: odvodnění terénu při patě obvodového zdiva, II. etapa (dohoda 715081). IDAV 57793, ulož. v archivu ARÚ AV ČR, Praha, v. v. i., 2015, sign. TX-2015-451.

- 2016: Dokončení záchranného archeologického výzkumu u kostela sv. Bartoloměje v Kočí (okr. Chrudim), Zprávy ČAS - Supplément 101, 38-39.

- 2016a: Záchranný archeologický výzkum u kostela sv. Václava v Lažanech u Skutče v roce 2016 - Rescue Archaeological Excavation at the Church of St. Wenceslas in Lažany by Skuteč (E Bohemia) in 2016, Chrudimský vlastivědný sborník 20, 97-142. 
FROLÍK, J. a kol., v tisku: Frolík, J.-Stránská, P.-Votrubová, J.-Emmerová, B.-Vaněk, D., People ,on the Margin‘: A Medieval Cemetery in Český Brod-Malechov (Central Bohemia), Interdiciplinaria Archaeologica Natural Sciences in Archaeology.

FROLÍK, J.-MÁCALOVÁ, M.-STRÁNSKÁ, P., 2016: Kostel sv. Václava v Jezbořicích (okr. Pardubice) a počátky pohřbívání u něho - St. Wenceslas Church of Jezbořice (District Pardubice) and Origin of Burials, Východočeský sborník historický 30, 5-97.

FROLÍK, J.-MUSIL, J., 2007: Záchranné archeologické výzkumy v Chrudimi v roce 2006 - Archäologische Rettungsgrabungen in Chrudim im J. 2006, Zprávy ČAS - Supplément 68, 46-48.

- 2016: Př́́spěvek k sociální identifikaci středověkých obyvatel Chrudimi na př́íkladu hřbitova u kostela Nanebevzetí Panny Marie - Ein Beitrag zur sozialen Identifikation der mittelalterlichen Einwohner von Chrudim am Beispiel des Friedhofs an der Maria Himmelfahrskirche, AH 41, 243-262.

FROLÍK, J.-SIGL, J., 1995: Chrudimsko v raném středověku. Vývoj osídlení a jeho proměny - Chrudim Region (East Bohemia) in Early Middle Ages. Development of Settlement and Related Structural Changes - Das Chrudimer Land im Frühmittelalter. Die Entwicklung der Besiedlung und seine strukturellen Probleme. Hradec Králové.

FROLÍK, J.-STRÁNSKÁ, P.-ŠVÉDOVÁ, J., v tisku: Výzkum u kostela sv. Petra a Pavla v Kostelci u Heřmanova Městce, AVČ 10.

FROLÍK, J.-ŠVÉDOVÁ, J., 2010: Záchranný archeologický výzkum u kostela sv. Martina v Hrochově Týnci (okr. Chrudim) - Archäologische Rettungsgrabung bei det Skt. Martinskirche in Hrochův Týnec (Bez. Chrudim), Zprávy ČAS - Supplément 78, 49-50.

FROLÍK, J.-TOMÁŠEK, M., 2000: Zpráva o záchranném archeologickém výzkumu v Nasavrkách (okr. Chrudim) v roce 1998 - Report of a Salvage Excavation at the Site of Nasavrky, District of Chrudim, in 1998, ZMHK26, 163-171.

FROLÍK, J.-VEPŘEKOVÁ, J., 2011: Zjištovací výzkum v Kutné Hoře u Kouřimské brány (otázka lokalizace zaniklého kostela sv. Jiří) - Feststellungsgrabung in Kutná Hora/Kuttenberg biem Kouřimer Tor (Die Lokalisationsfrage der untergegangenen Skt. Georgkirche), Zprávy ČAS - Supplément 81, 32-33.

HANULIAK, M., 1979: Hroby pod náhrobnými kameňmi v 11.-14. storočí - Gräber unter Grabsteinen im 11.-14. Jahrhundert, SlArch XXVII, 167-186.

HENDRYCHOVÁ, S.-FROLÍK, J., 2016: Kostel sv. Václava v Žabonosech (okr. Kolín) a jeho počátky - Die St. Wenzelkirche in Žabonosy (Bezirk Kolín) und ihre Anfänge, AH 41, 229-240.

CHYTIL, K., 1900: Soupis památek historických a uměleckých v politickém okresu chrudimském. Praha.

KLOUŽKOVÁ, A. a kol., 2014: Kloužková, A.-Zemenová, P.-Frolík, J.-Svobodová, L., Hodnocení středověké keramiky z Lažan u Chrudimi pomocí analýz XRF, XRD, OM, DSC-TG a RS - Beurteilung der mittelalterlichen Keramik aus Lažany bei Chrudim anhand der RAF, Röntgendiffraktion, optischen Mikroskopie, DSC-TG und der Raman-Spektroskopie, AH 39, 75-87.

KUČEROVÁ, I., 2013: Běstvina 2013. Konzervátorská a restaurátorská zpráva, rkp. ulož. na pracovišti Pražský hrad, Oddělení záchranných výzkumů Archeologického ústavu AV ČR, Praha, v. v. i.

LUTOVSKÝ, M. a kol., 2012: Terénní výzkumy Ústavu archeologické památkové péče středních Čech $\mathrm{v}$ roce 2011 - Field research of the Institute of Archaeological Heritage of Central Bohemia in the Year 2011, ASČ 16, 1021-1048.

MERHAUTOVÁ, A., 1971: Raně středověká architektura v Čechách. Praha.

ROJEK, J. K., 1871-1873: Biskupství Litomyšlské, PA IX, 737-758.

ŠILHOVÁ, A.-TRIBUlOVÁ, T., 2006: Běstvina (okr. Chrudim), kostel sv. Jana Křtitele (výzkum 2005). Konzervátorská a restaurátorská zpráva, rkp. ulož. na pracovišti Pražský hrad, Oddělení záchranných výzkumů Archeologického ústavu AV ČR, Praha, v. v. i.

UNGER, J., 2000: Pohřební ritus městského obyvatelstva 13. až 18. století v archeologických pramenech Moravy a Slezska - Der Grabritus der städtischen Bevölkerung im 13. bis 18. Jh. in archäologischen Quellen Mährens und Schlesiens, AH 25, 335-356.

- 2002: Pohřební ritus a zacházení s těly zemřelých v českých zemích (s analogiemi jinde v Evropě) v 1.16. století. In: Panoráma biologické a sociokulturní antropologie 9 (Malina, J., ed.), Brno.

\section{Zusammenfassung}

\section{Bestattungen im Hochmittelalter und in der Neuzeit in den Regionen Chrudim, Pardubice und Kolín}

Seit 2001 werden in den Regionen Chrudim und Pardubice (Ostböhmen) mit der Renovierung von Kirchen zusammenhängende archäologische Grabungen durchgeführt (Abb. 1). Einen 
Vergleich erlauben auch die Ergebisse weiterer Grabungen in den Regionen Kolín und Kutná Hora (Mittelböhmen - Abb. 2). Die in den Regionen Chrudim und Pardubice untersuchten Fundstellen umfassen die Umgebung von Städten (Chrudim, Přelouč, Skuteč), Dörfern (Běstvina, Jezbořice, Kočí, Lažany, Raná, Třebosice), Kleinstädten (Hrochův Týnec, Chrast, Nasavrky) und mit Klöstern verbundene Kirchenbauten (Podlažice, Práčov). Wir können uns mit 627 Gräbern beschäftigen. Als Vergleich dienen Dorfkirchen in den Regionen Kolín und Kutná Hora (Tismice, Žabonosy, Rostoklaty). Einen speziellen Fall stellt die bislang nicht beendete archäologische Grabung an der Friedhofskapelle bzw. am Karner der Allerheiligenkirche im Ortsteil Sedlec von Kutná Hora dar (bislang 1006 Skelette aus dem 13. bis 16. Jahrhundert). Abgesehen von den Gräbern in Kutná Hora - Sedlec können wir mit weiteren 128 Gräbern arbeiten.

Eine archäologische Grabung auf einem hochmittelalterlichen Friedhof bedeutet, dass ein beträchtlicher Teil der untersuchten Mächtigkeit durch die sog. Friedhofsschicht gebildet wird, d.h. durch die infolge einer Aushebung weiterer Gräber an einer Stelle, wo zuvor bereits bestattet wurde, entstandene Schicht. Eine Folge dessen ist die Entstehung einer Schicht mit einer Fülle von vereinzelten menschlichen Knochen, bei denen offensichtlich ist, ob ihre Lage intentional ist oder nicht (Abb. 3). Die Möglichkeit, Grabgruben in der Fläche zu unterscheiden, ist begrenzt. Etwas besser verhält es sich mit der Lesbarkeit der Kanten der Grabgruben an den Schnitten (Abb. 4). Die schlechte Lesbarkeit der Schnittstellen der Grabgruben bedeutet, dass lediglich solche Funde auf die Verfüllung eines Grabes bezogen werden können, die beim Präparieren eines Skeletts entstanden sind.

Es wurde ein einheitlicher Grabritus festgestellt. Es überwiegt eine Ost-West-Orientierung mit dem Kopf nach Westen. In den jüngeren Etappen (ab dem 16./17. Jahrhundert) wurde eine radiale Anordnung entdeckt (d.h. am häufigsten mit dem Kopf zur Kirche hin), und zwar besonders am Chorraum (Běstvina, Lažany - Abb. 5). Grund für die abweichende Orientierung können auch Objekte in der Friedhofsfläche gewesen sein, die von den Gräbern respektiert werden mussten (Chrudim). Es überwiegen Grabgruben mit einem Verstorbenen. Zu einem gewissen Prozentanteil identifizieren wir Bestattungen, bei denen sich mehrere Verstorbene in der Grabgrube befinden (Abb. 6). Gleichzeitige Bestattungen können nur durch die spezielle Lage der Gebeine belegt werden (Kutná Hora - Sedlec, Beinhaus - Abb. 7). Eine größere Anzahl von Verstorbenen finden wir in den Massengräbern vor (Kutná Hora - Sedlec, Beinhaus - Abb. 8). Nur ein geringer Teil an Bestatteten wurde nachweislich in Holzsärgen beigesetzt. Außer den über und unter einem Skelett erhalten gebliebenen Holzüberresten lassen in ursprünglicher Position gefundene Nägel die Verwendung eines Sarges erkennen. Ebenso beweiskräftig deutet der Fund von Randbeschlägen eines Sarges oder Verzierungen auf dem Deckel auf die Verwendung eines Sarges hin. Die Herrichtung eines Grabes in Form einer Gruft taucht erst im 17./18. Jahrhundert auf außerhalb von Kirchen liegenden Friedhöfen auf (Běstvina, Chrast-Chrašice, Jezbořice, Kočí).

Am häufigsten wurde ein Verstorbener auf dem Rücken liegend mit ausgestreckten Beinen und am Körper anliegenden Armen bestattet. Ungefähr ab dem 14. Jahrhundert nimmt die Zahl der Verstorbenen mit auf dem Bauch oder auf der Brust zusammengelegten Armen (Chrudim) zu. In Jezbořice beobachten wir eine Entwicklung von der Vorliebe für die Lage mit auf dem Bauch zusammengelegten Armen (ca. 1400 bis 1550) zu einer Rückkehr zur Lage mit am Körper anliegenden Armen. Eine ungleichmäßige Lage der Beine ist selten und hängt für gewöhnlich mit Schwierigkeiten bei der Beisetzung eines Verstorbenen in das Grab zusammen (Kutná Hora - Sedlec, Beinhaus - Abb. 9). Eine spezielle Gruppe bilden Massengräber. Beim Beinhaus in Kutná Hora - Sedlec wurden bislang vierzehn von ihnen entdeckt. In ihnen wurden die Verstorbenen mit dem Bestreben beigesetzt, den Raum bestmöglichst zu nutzen. Die Eckpartien wurden für die Beisetzung von Kleinkindern genutzt. Die meisten Verstorbenen wurden in der üblichen Lage beigesetzt. Es kommen auch Fälle vor, die darauf hindeuten, dass die Körper achtloses in die Grube hineingeworfen wurden (Abb. 8). Auf einigen Friedhöfen wurden Bereiche für eine vorrangige Beisetzung von Kindern abgegrenzt (Podlažice, Přelouč, Kutná Hora - Sedlec), jedoch war die Wahl der Orte in Bezug zur Kirche verschieden. 
Ein nicht eindeutiges Zeugnis liefern die archäologischen Grabungen auf die Frage der Kennzeichnung der Gräber. Die ikonographischen Quellen deuten darauf hin, dass zumindest ein Teil der Gräber gekennzeichnet wurde (mit einem einfachen Holzkreuz?). Archäologische Spuren solcher Kennzeichnungen liegen uns jedoch nicht vor. Seltener kommen Gräber vor, die mit unverzierten Steinplatten überdeckt sind (Běstvina, Podlažice, Žabonosy). Ab dem 16. Jahrhundert können wir ein Vorkommen von reichverzierten Grabplatten feststellen (z. B. Bítovany, Chrast-Chrašice, Morašice, Rosice), die heute überwiegend sekundär an Kirchenwänden weiterverwendet wurden. In intakter Lage wurde kein derartiger Grabstein entdeckt. Die Kennzeichnung der meisten Gräber war - falls es eine gab - offenbar einfach und von keiner langen Dauer. Sie wird durch die Beisetzung von mehreren Verstorbenen in einer einzigen Grabgrube belegt. Andererseits deutet die Aushebung von neuen Grabgruben, ohne dabei ältere Grabgruben zu respektieren, darauf hin, dass einige Gräber bestimmt nicht gekennzeichnet wurden. Als gewisses Modell kann die Hypothese von konkreten Grabstellen formuliert werden, die jeweils von einer bestimmten Familie genutzt wurden und gekennzeichnet waren. Falls die Grabstelle dann nicht mehr von dieser Familie genutzt wurde (Wegzug, Aussterben der Familie), ist die Kennzeichnung des Grabes zuweilen verschwunden und die Stelle wurde „frei“ für eine neue Nutzung.

Bei der Aushebung neuer Grabgruben kam es zur Störung oder zur vollständigen Beseitigung älterer Gebeine. Mit diesen ist man dann auf mehrere Art und Weisen verfahren. Am häufigsten ist ihre Verlagerung in die Friedhofsschicht. Nur vereinzelt können wir die Anhäufung älterer Gebeine am Rand von Grabgruben feststellen (Žabonosy). Manchmal haben wir festgestellt, dass die gefundenen Knochen gehoben wurden und an eine andere Stelle des Friedhofs gebracht wurden. (Lažany - Abb. 11; Kočí - Abb. 12). Eine andere Art und Weise menschliche Knochen beizusetzen waren die Beinhäuser. Das am besten erkannte Musterbeispiel ist das Beinhaus bei der St. Wenzelskirche in Lažany (Abb. 13). Die Grabung hat gezeigt, dass die Knochen mit dem Ziel darin aufgeschichtet wurden, den begrenzten Raum am besten zu nutzen. Wenn dieser nicht ausreichte, wurden die Knochen absichtlich verbrannt. Ein ähnliches Objekt wurde an der St. Jakobskirche in Přelouč teilweise untersucht (Abb. 14).

Nur wenige Erkenntnisse wurden über irreguläre Bestattungen und Gräberstätten außerhalb von sich bei Kirchen befindenden Friedhöfen gewonnen. Eine Gruppe von sechs Gräbern aus der zweiten Hälfte des 15. Jahrhunderts wurde am Rande von Český Brod in der Lage Malechov untersucht. Sie wurde als Gräbergruppe von Menschen interpretiert, die am Rande der damaligen Gesellschaft gelebt hatten (Landstreicher, Bettler, Viehtreiber u.ä.).

Die archäologischen Rettungsgrabungen bei den Kirchen in den Regionen Chrudim, Pardubice, Kolín und in Kutná Hora erlauben es, einen Einblick in die im Zeitraum zwischen dem 14. und 19. Jahrhundert in den genannten Gebieten gepflegten Bestattungssitten zu bekommen. Anhand von insgesamt 755 dokumentierten Gräber wird aufgezeigt, dass sich dort die Gebräuche beim Umgang mit den Körpern von Verstorbenen auf allgemeiner Ebene von den in anderen Gebieten gemachten Feststellungen nicht unterschieden haben.

Der vorliegende Artikel entstand als Bestandteil des von der Förderagentur der Tschechischen Republik geförderten Projektes 14-36935G „Die mittelalterliche Population im Zentrum und auf dem Land. Archäologie, Bioarchäologie und Genetik auf den Gräberfeldern der Prager Burg, in Mittel- und Ostböhmen“.

PhDr. Jan Frolík, CSc., Archeologický ústav AV ČR, Praha, v. v. i., Letenská 4, 11801 Praha 1, Česká republika,frolik@arup.cas.cz 
